Atmos. Chem. Phys., 13, 12233-12256, 2013

www.atmos-chem-phys.net/13/12233/2013/

doi:10.5194/acp-13-12233-2013

(c) Author(s) 2013. CC Attribution 3.0 License.

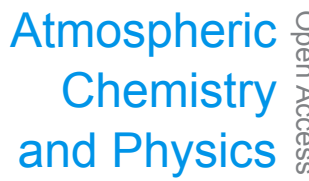

\title{
Biogenic and biomass burning organic aerosol in a boreal forest at Hyytiälä, Finland, during HUMPPA-COPEC 2010
}

\author{
A. L. Corrigan ${ }^{1}$, L. M. Russell ${ }^{1}$, S. Takahama ${ }^{1,2}$, M. Äijälä̈ ${ }^{3}$ M. Ehn ${ }^{3}$, H. Junninen ${ }^{3}$, J. Rinne $^{3}$, T. Petäjä ${ }^{3}$, \\ M. Kulmala ${ }^{3}$, A. L. Vogel ${ }^{4}$, T. Hoffmann ${ }^{4}$, C. J. Ebben $^{5}$, F. M. Geiger ${ }^{5}$, P. Chhabra ${ }^{6,7}$, J. H. Seinfeld ${ }^{6}$, D. R. Worsnop ${ }^{7}$, \\ W. Song ${ }^{8}$, J. Auld ${ }^{8}$, and J. Williams ${ }^{8}$ \\ ${ }^{1}$ Scripps Institution of Oceanography, University of California, San Diego, La Jolla, California, USA \\ ${ }^{2}$ Ecole Polytechnique Federale De Lausanne, Lausanne, Switzerland \\ ${ }^{3}$ Department of Physics, University of Helsinki, Helsinki, Finland \\ ${ }^{4}$ Institute of Inorganic Chemistry and Analytical Chemistry, Johannes Gutenberg University of Mainz, Mainz, Germany \\ ${ }^{5}$ Department of Chemistry, Northwestern University, Evanston, Illinois, USA \\ ${ }^{6}$ Department of Chemical Engineering, California Institute of Technology, Pasadena, California, USA \\ ${ }^{7}$ Aerodyne Research, Inc., Billerica, Massachusetts, USA \\ ${ }^{8}$ Department of Atmospheric Chemistry, Max Planck Institute for Chemistry, Mainz, Germany
}

Correspondence to: L. Russell (lmrussell@ucsd.edu)

Received: 23 May 2013 - Published in Atmos. Chem. Phys. Discuss.: 15 June 2013

Revised: 1 November 2013 - Accepted: 12 November 2013 - Published: 17 December 2013

\begin{abstract}
Submicron aerosol particles were collected during July and August 2010 in Hyytiälä, Finland, to determine the composition and sources of aerosol at that boreal forest site. Submicron particles were collected on Teflon filters and analyzed by Fourier transform infrared (FTIR) spectroscopy for organic functional groups (OFGs). Positive matrix factorization (PMF) was applied to aerosol mass spectrometry (AMS) measurements and FTIR spectra to identify summertime sources of submicron aerosol mass at the sampling site. The two largest sources of organic mass (OM) in particles identified at Hyytiälä were (1) biogenic aerosol from surrounding local forest and (2) biomass burning aerosol, transported 4-5 days from large wildfires burning near Moscow, Russia, and northern Ukraine. The robustness of this apportionment is supported by the agreement of two independent analytical methods for organic measurements with three statistical techniques. FTIR factor analysis was more sensitive to the chemical differences between biogenic and biomass burning organic components, while AMS factor analysis had a higher time resolution that more clearly linked the temporal behavior of separate $\mathrm{OM}$ factors to that of different source tracers even though their fragment mass spectrum were similar. The greater chemical sensitivity of the FTIR is attributed to the nondestructive preparation and the func-
\end{abstract}

tional group specificity of spectroscopy. The FTIR spectra show strong similarities among biogenic and biomass burning factors from different regions as well as with reference OM (namely olive tree burning organic aerosol and $\alpha$-pinene chamber secondary organic aerosol (SOA)). The biogenic factor correlated strongly with temperature and oxidation products of biogenic volatile organic compounds (BVOCs), included more than half of the oxygenated OFGs (carbonyl groups at $29 \%$ and carboxylic acid groups at $22 \%$ ), and represented $35 \%$ of the submicron OM. Compared to previous studies at Hyytiälä, the summertime biogenic $\mathrm{OM}$ is 1.5 to 3 times larger than springtime biogenic OM $\left(0.64 \mu \mathrm{g} \mathrm{m}^{-3}\right.$ and $0.4 \mu \mathrm{g} \mathrm{m}^{-3}$, measured in 2005 and 2007, respectively), even though it contributed only $35 \%$ of OM. The biomass burning factor contributed $25 \%$ of $\mathrm{OM}$ on average and up to $62 \%$ of $\mathrm{OM}$ during three periods of transported biomass burning emissions: 26-28 July, 29-30 July, and 8-9 August, with OFG consisting mostly of carbonyl (41\%) and alcohol $(25 \%)$ groups. The high summertime terrestrial biogenic $\mathrm{OM}\left(1.7 \mu \mathrm{g} \mathrm{m}^{-3}\right)$ and the high biomass burning contributions $\left(1.2 \mu \mathrm{g} \mathrm{m}^{-3}\right)$ were likely due to the abnormally high temperatures that resulted in both stressed boreal forest conditions with high regional BVOC emissions and numerous wildfires in upwind regions. 


\section{Introduction}

Boreal forests produce a large amount of global SOA from the emissions of high molecular weight, reactive biogenic volatile organic compounds (BVOCs) such as monoterpenes and sesquiterpenes (Seinfeld and Pandis, 2006). BVOC emissions are higher and generally more reactive than anthropogenic VOC emissions, making them potent sources of organic aerosol (Atkinson, 2000; Eerdekens et al., 2009; Laaksonen et al., 2008; Yassaa et al., 2012). Globally the oxidation of BVOCs is estimated to produce $12-70 \mathrm{TgC} \mathrm{yr}^{-1}$ of SOA (Hallquist et al., 2009), and anthropogenic emissions may significantly enhance biogenic SOA formation (Carlton et al., 2010; Hoyle et al., 2011).

Biogenic emissions are one way that forests play an important role in the emission of primary and secondary organic aerosol (POA, SOA). It is believed that biomass burning is the largest source ( $90 \%$ ) of global primary organic carbon (POC), estimated at 31-45 $\mathrm{TgC} \mathrm{yr}^{-1}$ (Bond et al., 2004). Biomass burning also emits large amounts of organic trace gases that can react in the atmosphere to form SOA; however, the contribution of biomass burning emissions to SOA formation is unknown (Hallquist et al., 2009). Field studies report a range of SOA concentrations from aging fire plumes, with enhancement of organic mass (OM) ranging from 30 to $400 \%$ relative to fresh plume conditions (DeCarlo et al., 2010; Heringa et al., 2011; Yokelson et al., 2009). These enhancements are consistent with smog chamber studies of SOA formation from biomass burning emissions (Cubison et al., 2011; Hennigan et al., 2011).

Several different apportionment techniques have been used to identify the biogenic contribution to total OM, most recently including factor analysis, organic tracers, ${ }^{14} \mathrm{C}$, and OC/EC (organic to elemental carbon) analysis (Table 1). The biogenic SOA fraction has been found to contribute from 10 to $65 \%$ of the measured $\mathrm{OM}$ in or near forested regions (Finessi et al., 2012; Fu et al., 2010; Schwartz et al., 2010; Szidat et al., 2009). The majority of studies used factor analysis of aerosol mass spectrometry (AMS) measurements, in conjunction with tracer correlations and air mass back trajectories to identify biogenically influenced OM. The AMSderived biogenic factors were identified as oxygenated organic aerosol (OOA), typically having $\mathrm{O} / \mathrm{C}$ ratios ranging from 0.22 to 0.54 (Finessi et al., 2012; Raatikainen et al., 2010; Setyan et al., 2012; Slowik et al., 2010). The OOA factors correlated strongly $(r>0.7)$ with BVOC oxidation products and the spectra were enhanced with a few mass fragments $(m / z 29,43$, and 58) that have been identified in SOA from $\alpha$-pinene photooxidation (Shilling et al., 2009) and from plant emission photooxidation (Kiendler-Scharr et al., 2009). However, these mass fragments are not specific to biogenically influenced OOA factors and have been observed in hydrocarbon-like organic aerosol (HOA), biomass burning organic aerosol (BBOA), and semivolatile oxygenated organic aerosol (SV-OOA or OOA-2) (Slowik et al., 2010;
Sun et al., 2011; Zhang et al., 2005). Recent work has identified a specific mass fragment associated with isoprene SOA ( $\mathrm{m} / \mathrm{z}$ 82) (Budisulistiorini et al., 2013; Lin et al., 2012); however, no unique mass fragments have yet been identified for monoterpene SOA in ambient aerosol. Other apportionment techniques have applied a combination of factor, radiocarbon, and tracer analysis to quantify the biogenic fraction (Minguillon et al., 2011), but also indicated substantial uncertainties in these methods given the greater biogenic fraction identified during wintertime $(30 \%)$ than summertime $(23 \%)$ at the Mediterranean city of Barcelona (Minguillon et al., 2011).

In addition to AMS factor analysis, Fourier tranform infrared (FTIR) spectroscopy provides quantitative OM and functional group concentrations that have been used to identify $\mathrm{OM}$ sources by using characteristic organic functional group (OFG) mixtures to specify the source factors (Ahlm et al., 2013; Frossard et al., 2011; Hawkins and Russell, 2010; Hawkins et al., 2010; Liu et al., 2012; Russell et al., 2011; Schwartz et al., 2010; Shaw et al., 2010; Takahama et al., 2011). Comparison of factor analysis from simultaneous AMS and FTIR measurements can reduce the uncertainties of PMF, providing a more robust OM apportionment to sources (Frossard et al., 2011; Hawkins and Russell, 2010; Liu et al., 2012).

The Hyytiälä United Measurement of Photochemistry and Particles-Comprehensive Organic Particle and Environmental Chemistry (HUMPPA-COPEC 2010) study was conducted at the SMEAR II (Hari and Kulmala, 2005) boreal forest research station in Hyytiälä, Finland, in July and August 2010 with an impressive suite of simultaneous particleand gas-phase measurements. The primary goals of the campaign include investigating summertime aerosol chemistry and photochemistry of BVOCs (Williams et al., 2011). In this analysis, we focus on the characterization of the organic aerosol during HUMPPA-COPEC 2010 using two independent analytical methods of organic measurement (FTIR and AMS techniques) and three separate statistical methods (clustering, factorization, potential source contributions) to apportion OM to biogenic and biomass burning sources. We also compare the differences in the chemical composition of biogenic and biomass burning particles to previous field campaigns and reference materials. This approach allows us to provide the most robust apportionment of OM for summertime Hyytiälä completed to date and to identify the relative advantages of different $\mathrm{OM}$ measurement techniques.

\section{Methods}

\subsection{Sample collection}

Submicron particles and gases were sampled from 12 July to 12 August 2010 in southern Finland (latitude $61^{\circ} 51^{\prime} \mathrm{N}$; longitude $24^{\circ} 17^{\prime} \mathrm{E}$ ) at $181 \mathrm{~m}$ above sea level (ma.s.l.). 
Table 1. Summary of biogenic and biomass burning apportionment from previous studies influenced by forest OM.

\begin{tabular}{|c|c|c|}
\hline Reference & Project & Key findings \\
\hline \multicolumn{3}{|r|}{ Factor analysis } \\
\hline This study & $\begin{array}{l}\text { HUMPPA- } \\
\text { COPEC12 }\end{array}$ & $\begin{array}{l}\mathrm{BIO}_{\mathrm{FTIR}} \text { and } \mathrm{BOA}_{\mathrm{AMS}} \text { were separated from aged BB aerosol and captured } \\
\text { local sawmill operations. BIO } \\
\text { ture and the factor spectra correlated strongly with } \alpha \text {-pinene oxidation prod- } \\
\text { ucts from } \mathrm{OH} \text { oxidation. }\end{array}$ \\
\hline Takahama et al. (2011) & $\begin{array}{l}\text { Whistler, Canada; } \\
\text { summer } 2009\end{array}$ & $\begin{array}{l}\text { BIOFTIR was separated from BB } \text { FTIR, and contained high fractions of al- }_{\text {cohol and carbonyl organic functional groups. PSCF analysis indicated }} \\
\text { BIOFTIR factor originated from forested regions in northern Canada. }\end{array}$ \\
\hline Schwartz et al. (2010) & $\begin{array}{l}\text { Whistler, Canada; } \\
\text { summer } 2008\end{array}$ & $\begin{array}{l}\text { PMF attributed } 65 \% \text { of OM to biogenic sources. BIOFTIR was domi- } \\
\text { nated by oxygenated species: carbonyl, carboxylic acid, and alcohol or- } \\
\text { ganic functional groups, and correlated strongly with monoterpenes and } \\
\text { MVK/MACR. }\end{array}$ \\
\hline Budisulistiorini et al. (2013) & $\begin{array}{l}\text { Atlanta, Georgia; } \\
\text { summer and fall } \\
2011\end{array}$ & $\begin{array}{l}\text { A summertime OOA factor (IEPOX) contributing } 33 \% \text { of OM was iden- } \\
\text { tified and attributed to isoprene SOA. The factor correlated strongly with } \\
\text { laboratory-generated SOA from isoprene epoxydiols (IEPOX) and con- } \\
\text { tained a characteristic mass fragment, } m / z 82 \text {. }\end{array}$ \\
\hline Setyan et al. (2012) & $\begin{array}{l}\text { CARES, } \\
\text { Sacramento Valley; } \\
\text { summer } 2010\end{array}$ & $\begin{array}{l}\text { A more-oxygenated organic aerosol (MO-OOA } \mathrm{AMS} \text { ) component was asso- } \\
\text { ciated with BSOA. Correlations with MVK/MACR and enhanced } m / z 29 \\
\left(\mathrm{CHO}^{+}\right) \text {signature confirm the biogenic influence on this factor. MO- } \\
\mathrm{OOA}_{\mathrm{AMS}} \text { was enhanced when anthropogenic emissions increased and } \\
\text { BVOCs were abundant. }\end{array}$ \\
\hline Finessi et al. (2012) & $\begin{array}{l}\text { Hyytiälä, Finland; } \\
\text { spring } 2007\end{array}$ & $\begin{array}{l}\text { Clean, marine-influenced, air masses were linked to a less oxygenated } \\
\text { aerosol }(\mathrm{OOA} 2 \mathrm{AMS}) \text { and carbonyl/carboxylic-enhanced aerosol (Terpene- } \\
\left.\mathrm{SOA}_{N M R}\right) \text {. Terrestrial biogenic secondary organic aerosol (BSOA) ac- } \\
\text { counted for } 30 \% \text { of OA. }\end{array}$ \\
\hline Slowik et al. (2007) & $\begin{array}{l}\text { Egbert, Ontario; } \\
\text { summer } 2007\end{array}$ & $\begin{array}{l}\text { An OOA } 2 \text { AMS factor was found to correlate strongly with MACR/MVK } \\
\text { tracers and temperature, suggesting influence from BSOA. Model calcula- } \\
\text { tions and remote sensing measurements indicate BSOA impacted regional } \\
\text { aerosol loadings. }\end{array}$ \\
\hline Raatikainen et al. (2010) & $\begin{array}{l}\text { Hyytiälä, Finland; } \\
\text { April } 2005\end{array}$ & $\begin{array}{l}\text { Factor analysis and back trajectories attributed an OOA } 2 \text { AMS factor to local } \\
\text { VOC oxidation (e.g. BSOA). Volatility study found that OOA } 2 \text { AMS was } \\
\text { much more volatile than the more oxidized OOA } 1 \text { AMS factor. }\end{array}$ \\
\hline Williams et al. (2007) & $\begin{array}{l}\text { ICARTT, Chebogue } \\
\text { Pt; summer } 2004\end{array}$ & $\begin{array}{l}\text { Factor analysis, back trajectories, and correlations with BVOC oxida- } \\
\text { tion products helped identify two biogenic components: isoprene } \mathrm{TAG} \text { and } \\
\text { terpene } \\
\text { organic oxidation, accounting for } 20 \% \text { of OM. Both factors had high } \\
\text { oractions }(>75 \%) \text {. }\end{array}$ \\
\hline
\end{tabular}

\begin{tabular}{|c|c|c|}
\hline \multicolumn{3}{|r|}{ Organic tracer analysis } \\
\hline Offenberg et al. (2011) & $\begin{array}{l}\text { RTP, North } \\
\text { Carolina; } 2006\end{array}$ & $\begin{array}{l}\text { Isoprene SOA accounted for up to } 40 \% \text { of OM in the summer months and } \\
\text { was highly temperature dependent. }\end{array}$ \\
\hline Fu et al. (2010) & $\begin{array}{l}\text { MTX2006; east } \\
\text { China }\end{array}$ & $\begin{array}{l}\text { Isoprene-derived secondary organic carbon (SOC) was } 7 \text { times greater than } \\
\text { monoterpene-derived SOC. Biogenic SOC accounted for } 10 \% \text { of OC, and } \\
60 \% \text { of SOC. }\end{array}$ \\
\hline \multicolumn{3}{|r|}{${ }^{14} \mathrm{C}$ and $\mathrm{OC} / \mathrm{EC}$ analysis } \\
\hline Szidat et al. (2009) & $\begin{array}{l}\text { Goteborg, Sweden; } \\
2005,2006\end{array}$ & $\begin{array}{l}\mathrm{OC}_{\mathrm{BIO}} \text { was the dominant } \mathrm{OM} \text { source during summer months }(40 \%) \text {. The } \\
\text { presence of BSOA during the winter months in Sweden suggests that POA } \\
\text { from wood burning could contribute to this aerosol fraction. }\end{array}$ \\
\hline Lewis et al. (2004) & Summer 1999 & $\begin{array}{l}\text { Biogenic contribution to organic carbon was identified; however, it was un- } \\
\text { determined what fraction was primary and what fraction was secondary. }\end{array}$ \\
\hline \multicolumn{3}{|r|}{ Classification analysis } \\
\hline Chen et al. (2009) & $\begin{array}{l}\text { AMAZE-08; } \\
\text { Manaus, Brazil }\end{array}$ & $\begin{array}{l}\text { Class of aerosol consistent with low sulfate concentrations, high organics, } \\
\text { in-basin flow, and correlation with isoprene and monoterpenes was deter- } \\
\text { mined to be BSOA. }\end{array}$ \\
\hline
\end{tabular}


Atmospheric particles were measured by FTIR spectroscopy, compact time-of-flight mass spectrometry (C-ToF-AMS), atmospheric pressure chemical ionization mass spectrometry (APCI-MS), X-ray fluorescence (XRF), and scanning transmission X-ray microscopy with near-edge absorption fine structure (STXM-NEXAFS). A suite of gas-phase species, including $\mathrm{SO}_{2}, \mathrm{CO}, \mathrm{NO}_{\mathrm{x}}, \mathrm{O}_{3}, \mathrm{OH}$, and biogenic VOCs, were also measured during the campaign. A complete description of the field site and instruments deployed is provided by Williams et al. (2011).

\subsection{FTIR and XRF analysis}

Submicron particles were collected $4 \mathrm{~m}$ above ground level, approximately midcanopy level, in temperature-controlled housing on $37 \mathrm{~mm}$ Teflon filters (Pall Inc., $37 \mathrm{~mm}$ diameter, $1.0 \mu \mathrm{m}$ pore size) located downstream of a $1 \mu \mathrm{m}$ sharp-cut cyclone (SCC 2.229 $\mathrm{PM}_{1}$, BGI Inc.). The aerosol particles were dried (Silica orange gel 13767, Sigma-Aldrich, USA) to below $25 \%$ relative humidity prior to the cyclone. Back filters were also collected to quantify VOC adsorption and artifacts; however, absorbance on all back filters was below limit of detection (LOD). Filter duration varied from 6 to $12 \mathrm{~h}$, in addition to duplicate $24 \mathrm{~h}$ filters. To reduce evaporative losses, samples were stored and transported at $0{ }^{\circ} \mathrm{C}$ prior to analysis in La Jolla, California, by a Tensor 27 spectrometer equipped with a DTGS detector (Bruker, Billerica, MA). Organic functional groups were quantified from FTIR absorbance spectra based on the linear response of peak area to the number of moles of organic bonds (Gilardoni et al., 2007; Maria et al., 2002, 2003). An automated peak-fitting algorithm described by Russell et al. (2009b) and Takahama et al. (2013) was used to quantify organic functional groups, which included saturated aliphatic $\mathrm{C}-\mathrm{CH}$ (alkane), unsaturated aliphatic $\mathrm{C}=\mathrm{CH}$ (alkene), aromatic $\mathrm{C}=\mathrm{CH}$, nonacid organic hydroxyl $\mathrm{C}-\mathrm{OH}$ (alcohol), primary amine $\mathrm{C}-\mathrm{NH}_{2}$, nonacid carbonyl $\mathrm{C}=\mathrm{O}$ (aldehyde, ketone or ester carbonyl), and carboxylic acid $\mathrm{COOH}$ groups. Alkene and aromatic groups were below the limit of quantification (LOQ) for all samples collected during the field campaign. Both organonitrate and organosulfate groups were detected at $860 \mathrm{~cm}^{-1}$ and $876 \mathrm{~cm}^{-1}$, respectively. A modified peak-fitting algorithm described by Day et al. (2010) was used to quantify organonitrate groups. Due to overlapping absorbance of carbonate and bisulfate at $876 \mathrm{~cm}^{-1}$, a hexane rinsing method described in Gilardoni et al. (2007) and in Russell et al. (2009b) is used to quantify organosulfate. Twenty-four (24) of 65 samples contained absorbance at $876 \mathrm{~cm}^{-1}$, but no samples were above the LOQ.

After FTIR analysis, a subset of filters was sent to Chester Labnet (Tigard, Oregon) for XRF analysis to provide concentrations of $\mathrm{Na}$ and heavier elements (Maria et al., 2003; Russell et al., 2009b). Elements that were above LOQ on more than $30 \%$ of the filters include $\mathrm{Al}, \mathrm{Si}, \mathrm{P}, \mathrm{S}, \mathrm{K}, \mathrm{Ca}, \mathrm{V}, \mathrm{Cr}, \mathrm{Fe}$, $\mathrm{Co}, \mathrm{Cu}, \mathrm{Zn}, \mathrm{Se}, \mathrm{Br}$, and $\mathrm{Pb}$.

\subsection{Aerosol mass spectrometry}

The Aerodyne AMS (Aerodyne Research Inc., Billerica, MA; Canagaratna et al., 2007) measures submicron particle chemical composition using time-of-flight mass spectrometry. The variant of the device used in this study was a C-ToF AMS with 5 min time resolution that features a shorter than usual particle time-of-flight chamber, which results in increased transmission of both particles and gas, and therefore also a larger air signal than in most AMS designs (Drewnick et al., 2005).

The AMS aerosol mass is then assigned into subgroups of different chemical composition: sulfate, organic, nitrate, ammonium, and chloride mass fragments (Allan et al., 2003; Alfarra et al., 2004). The AMS does not efficiently vaporize compounds that are "refractory" at $600^{\circ} \mathrm{C}$, such as sea salt, black carbon or crustal material. Particulate water is not included in the AMS measurements. The collection efficiency (CE) of 0.43 was determined from a comparison with differential mobility particle sizer (DMPS; Aalto et al., 2001)-derived mass concentrations in size range 3-600 nm. The DMPS number distributions were converted to volume distributions, and integrated over the size range in question. Black carbon (BC) volume derived from an aethalometer was then subtracted and the remaining volume multiplied by time-dependent particle density, estimated with a weighted average of chemical species densities from the AMS. The neutral-aerosol (base) CE was determined from the average ratio of AMS total mass per DMPS-derived mass (minus BC) and was found to be 0.43 with a standard deviation of 0.08. This CE was applied for time periods when the aerosol acidity was neutral, as determined by the ratio of ammonium to sulfate plus nitrate. For periods with nonneutralized sulfate, when the molar ammonium was substantially less than twice the molar sulfate, indicating elevated aerosol acidity, a higher value was used, based on a linear correction function similar to that of Quinn et al. (2006) $\left(\mathrm{EB}=-(1-\mathrm{CE})\left(\left[\mathrm{NH}_{4}\right] /\left[\mathrm{SO}_{4}\right]\right)+1\right.$, where $\left.\mathrm{CE}=0.43\right)$. During the measurement period the mass fraction of nitrates was consistently low, below $10 \%$, causing no distinguishable CE effects.

Oxygen-to-carbon ratios $(\mathrm{O} / \mathrm{C})$ were calculated from two independent techniques: AMS and FTIR. C-ToF-AMS O/C ratios were estimated from the $f_{44}$, ratio of $\mathrm{m} / z 44\left(\mathrm{COO}^{+}\right.$ ion) relative to the total ion mass, proxy described by Aiken et al. (2008). For FTIR measurements, O/C was determined by the sum of oxygen atoms in the oxygen-containing functional groups (alcohol, carboxylic acid, and carbonyl), which was normalized by the total carbon atoms of all organic functional groups measured (Russell et al., 2009b).

\subsection{Organic acids}

On-line measurements of organic acids in gas- and particlephase during HUMPPA-COPEC 2010 were carried out with 
an atmospheric pressure chemical ionization mass spectrometer (APCI-MS; Finnigan LCQ; Kuckelmann et al., 2000). The measurements were conducted in the main SMEAR II cottage, next to the C-ToF-AMS, both sampling from a stainless steel inlet at midcanopy height $(8 \mathrm{~m})$.

Ambient aerosol was enriched in front of the APCI-MS by using a miniature versatile aerosol concentration enrichment system (mVACES; Geller et al., 2005) to improve the sensitivity by a factor of approximately 7.5 , while retaining the measurement frequency of one spectrum per minute. Afterwards, the enriched aerosol stream was led through a heated ceramic tube $\left(350^{\circ} \mathrm{C}\right)$ in order to vaporize the aerosol particles for ionization. The ionization was achieved by using corona discharge at $3 \mathrm{kV}$, which produces $\mathrm{O}_{2}^{-}$-ions as primary ions. Consequently, all gaseous molecules, having higher gas-phase acidities than $\mathrm{O}_{2}^{-}$, were ionized. In intervals of $3 \mathrm{~h}$, gas-phase compounds were measured for half an hour, by switching a high-efficiency particulate absorption (HEPA) filter in front of the ion source. Linear interpolation between the gas-phase measurements and subtraction from the total signal resulted in the particle-phase signal. A more detailed description is provided by Vogel et al. (2013). Particulate organic acids correlated well with FTIR carboxylic acid functional groups and FTIR OM (see the Supplement for more details).

\subsection{Additional measurements}

Other supporting particle-phase and gas-phase measurements include $\mathrm{O}_{3}, \mathrm{SO}_{2}, \mathrm{CO}, \mathrm{NO}_{\mathrm{x}}$, and meteorological data that are recorded throughout the year at the Hyytiälä SMEAR-II site, details of which are described by Hari and Kulmala (2005) and Junninen et al. (2009). Proton transfer reaction mass spectrometer (PTR-MS, (Lindinger et al., 1998; Taipale et al., 2008)) provided mixing ratios of several VOCs (Williams et al., 2011). Pentane and butane were measured by a modified fast GC-MS described in detail by Johnson (2011). Monoterpenes and chiral monoterpenes were measured by gas chromatography-mass spectrometry (GCMS) (Yassaa et al., 2012; Yassaa and Williams, 2005). Black carbon mass concentrations were measured by an aethalometer (Margee Scientific). A comprehensive list of the instrumentation, including time resolutions, detection limits, and inlet locations, is provided by Williams et al. (2011).

\subsection{PMF and PSCF}

Positive matrix factorization (PMF) was applied to FTIR and AMS spectra to identify the components that contribute to the time series of the measured particle-phase chemical mixtures (Paatero and Tapper, 1994). Recently PMF has been successfully applied to both FTIR and AMS spectra to separate organic components associated with different sources (Frossard et al., 2011; Hawkins and Russell, 2010; Russell et al., 2009b; Schwartz et al., 2010; Ulbrich et al., 2009; Zhang et al., 2011). PMF was applied to both FTIR and AMS spectra. Results for 2, 3, 4, 5, and 6 factor solutions for each measurement type were examined for FPEAK (rotation) values from -1.2 to 1.2 and seed values of 1,10 , and 100. Solutions were considered to be potential candidates if explained variation and $\mathrm{OM}$ reconstruction was maximized, $q$ value was minimized, colinearity amongst the factors was reduced, factor spectra were nondegenerate, and tracer correlations were meaningful. Additional details describing PMF parameters are listed in the Supplement.

Potential source contribution function (PSCF) was used to identify geographical source regions that were associated with the observed aerosol composition and air mass back trajectories, based on co-occurrence of high concentration samples (Pekney et al., 2006). PSCF used 4-day air mass back trajectories calculated by the HYbrid Single Particle Lagrangian Integrated Trajectory (HYSPLIT) model (Draxler and Rolph, 2013). Hourly back trajectories were calculated $200 \mathrm{~m}$ above ground level at Hyytiälä for the duration of the campaign. PSCF was calculated for submicron OM, concentrations and mass fractions of organic functional groups, and PMF factors from FTIR and AMS.

\section{Results from HUMPPA-COPEC campaign measurements}

\subsection{Aerosol particle composition (organic, inorganic, and elemental)}

Hyytiälä is influenced by biogenic aerosols, transported pollution from continental Europe and western Russia, and occasionally impacted by biomass burning emissions in the summer months (Williams et al., 2011). During the summer measurements of 2010, a high-pressure region, stationed east of Finland for an extended period of time, produced abnormally high temperatures $\left(T_{\max }=32.4^{\circ} \mathrm{C}, T_{\mathrm{avg}}=20.0^{\circ} \mathrm{C}\right)$. The high temperatures resulted in enhanced biogenic $\mathrm{OM}$ as well as increased wildfires in western Russia. The chemical composition of biogenically influenced submicron particles measured at Hyytiälä is described in detail below.

\subsubsection{Organic mass and functional group composition: campaign averages and high-OM events}

Particle-phase mass at Hyytiälä was dominated by organic components (with an average mass concentration of $4.4 \mu \mathrm{g} \mathrm{m}^{-3}$ ) and varied significantly throughout the campaign $\left( \pm 3.1 \mu \mathrm{g} \mathrm{m}^{-3}\right)$ due to local sources (i.e. sawmill activity; Eerdekens et al., 2009; Liao et al., 2011) and long-range transport of Russian biomass burning emissions (Fig. 1; Williams et al., 2011). Submicron particle mass $\left(\mathrm{PM}_{1}\right)$ measured as the sum of nonrefractory components by C-ToFAMS, BC by aethelometer, and metal oxides by XRF (plus associated oxygen estimated by $\mathrm{SiO}_{2}, \mathrm{Al}_{2} \mathrm{O}_{3}, \mathrm{Fe}_{2} \mathrm{O}_{3}$, and $\mathrm{CaCO}_{3}$; Usher et al., 2003) was on average $6.8 \mu \mathrm{g} \mathrm{m}^{-3}$ with 
Table 2. Mean and standard deviation of measured OM, organic functional groups, sulfate, ammonia, nitrate, black carbon and mineral oxides for HUMPPA-COPEC: campaign average, sawmill and fire periods (concentrations in $\mu \mathrm{g} \mathrm{m}^{-3}$ ). Metal oxides were assumed to be $\mathrm{SiO}_{2}, \mathrm{Al}_{2} \mathrm{O}_{3}, \mathrm{Fe}_{2} \mathrm{O}_{3}$, and $\mathrm{CaCO}_{3}$ (Usher et al., 2003); their concentrations were calculated from corresponding elemental concentrations quantified by XRF. Organic functional groups from FTIR, including alcohol (pink), alkane (blue), carboxylic acid (green), amine (orange), and carbonyl (teal).

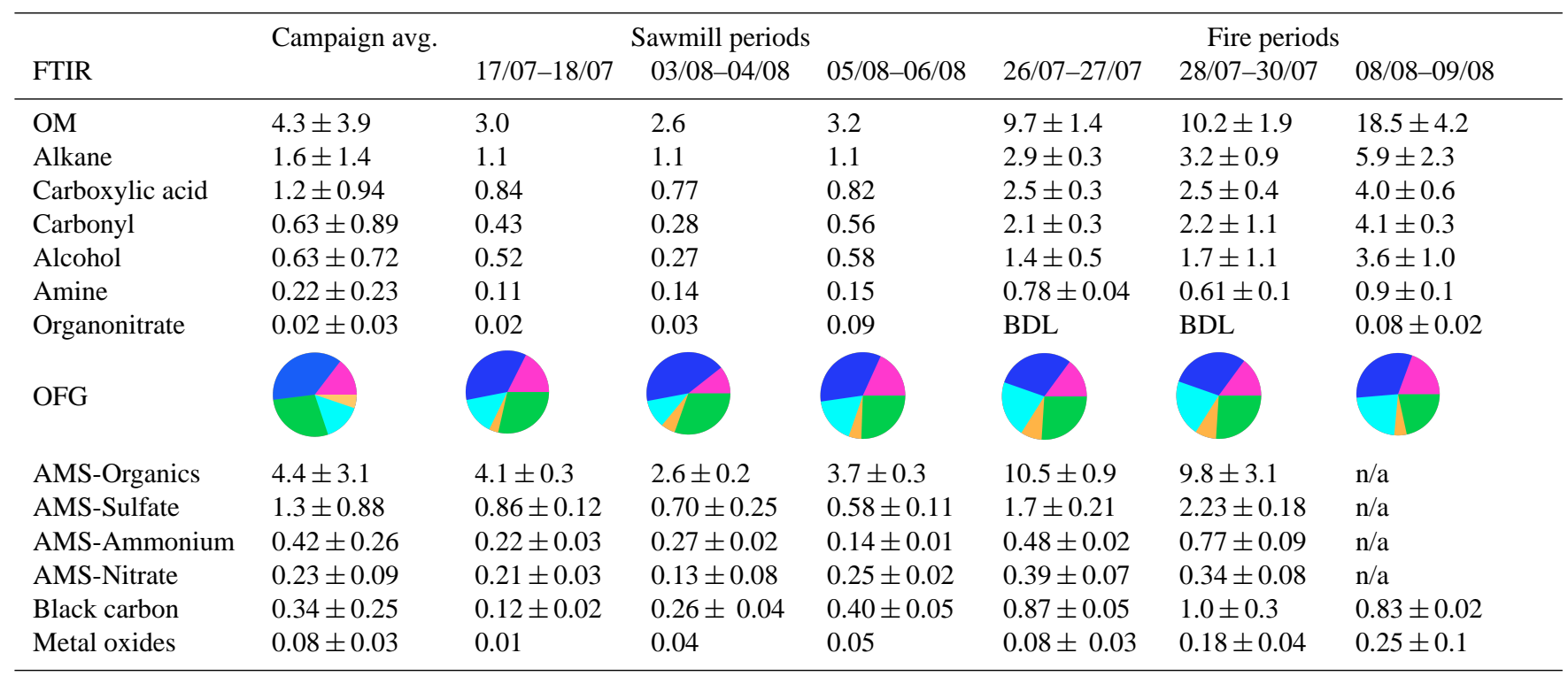

a standard deviation of $4.6 \mu \mathrm{g} \mathrm{m}^{-3}$, with organic compounds dominating the submicron fraction $(64 \%)$, followed by sulfate $(20 \%)$, ammonium $(6 \%)$, black carbon $(5 \%)$, nitrate and metal oxides (2\%) (Table 2). Total submicron OM measured by FTIR was $4.3 \pm 3.9 \mu \mathrm{g} \mathrm{m}^{-3}$, with the organic functional group composition dominated by alkane $(37 \%)$ and carboxylic acid (28\%) groups, followed by carbonyl $(15 \%)$, alcohol $(15 \%)$, and finally amine (5\%) groups (Table 2). Organosulfate groups were detected throughout the campaign, but they were below the limit of quantification. The measured range of organosulfate group was below 5$25 \mathrm{ng} \mathrm{m}^{-3}$, consistent with the measured ranges of molecular concentrations of organosulfates reported for polluted (Gomez-Gonzalez et al., 2012) and rural (Yttri et al., 2011) forested sites in northern Europe.

The HUMPPA-COPEC campaign was punctuated by two types of high-OM events: sawmill activity and transported emissions from Russian wildfires (Eerdekens et al., 2009; Williams et al., 2011). Nearby sawmill (Korkeakoski, Finland, located $10 \mathrm{~km} \mathrm{SE}$ of Hyytiälä) activity was identified by an enrichment of ( + - $\alpha$-pinene over its ( -$)$ - $\alpha$-pinene enantiomer, attributed to a metabolic response to wounding, coinciding with high nighttime monoterpene and isoprene concentrations (Williams et al., 2011; Yassaa and Williams, 2007). Sawmill activity was detected at the Hyytiälä site on the nights of 17 July and 3 and 5 August, during which OM increased from 2.6 to $3.2 \mu \mathrm{g} \mathrm{m}^{-3}$ (as indicated by the bars on the top axis of Fig. 1). During the sawmill events, the OM had higher fractions of sulfate compared to the campaign av- erage (Table 2). OM during sawmill events had more oxygenated organic functional groups (O-OFG), but those time periods were also characterized by a slightly higher fraction of alkane group mass compared to the campaign average, namely $40-44 \%$ rather than $37 \%$ (Table 2 ). The combustion associated with the sawmill operation and short transport time of fresh biogenic aerosol $(<1 \mathrm{~h})$ are likely responsible for the higher alkane fraction. Organonitrate groups were near the campaign average $\left(0.02 \mu \mathrm{g} \mathrm{m}^{-3}\right)$ during the sawmill periods, except for the night of 5 August $\left(0.09 \mu \mathrm{g} \mathrm{m}^{-3}\right)$.

Acetonitrile $\left(\mathrm{CH}_{3} \mathrm{CN}\right)$ and carbon monoxide $(\mathrm{CO})$ are gas-phase tracers used to identify periods influenced by regional biomass burning (Lobert et al., 1990), in addition to particle-phase tracers potassium and bromine (Andreae et al., 1996) (Fig. 1d and e). Increases in potassium (K) and bromine $(\mathrm{Br})$ concentrations were observed on 26-28 July, 29-30 July, and 8-9 August, showing fire period averages of 380 and $8.6 \mathrm{ng} \mathrm{m}^{-3}$, respectively, with percent increases over background (project minimum) concentrations of $1800 \%$ and $330 \%$ (Fig. 1e). Elevated concentrations of acetonitrile $(0.45 \mathrm{ppb}, 460 \%)$ and CO (220 ppt, $120 \%)$ were observed during these periods (Fig. 1e). Fire periods were dominated by $\mathrm{O}-\mathrm{OFG}$, with $2.1-4.1 \mathrm{\mu g} \mathrm{m}^{-3}$ carbonyl groups and $2.5-$ $4.0 \mu \mathrm{g} \mathrm{m}^{-3}$ carboxylic acid groups (Table 2). OM during fire periods was two to five times greater than the campaign average OM, with the highest concentration $\left(21 \mu \mathrm{g} \mathrm{m}^{-3}\right)$ on 9 August. The highest concentrations of black carbon $\left(1.84 \mu \mathrm{g} \mathrm{m}^{-3}\right)$ and metal oxides $\left(0.25 \mu \mathrm{g} \mathrm{m}^{-3}\right)$ were also 


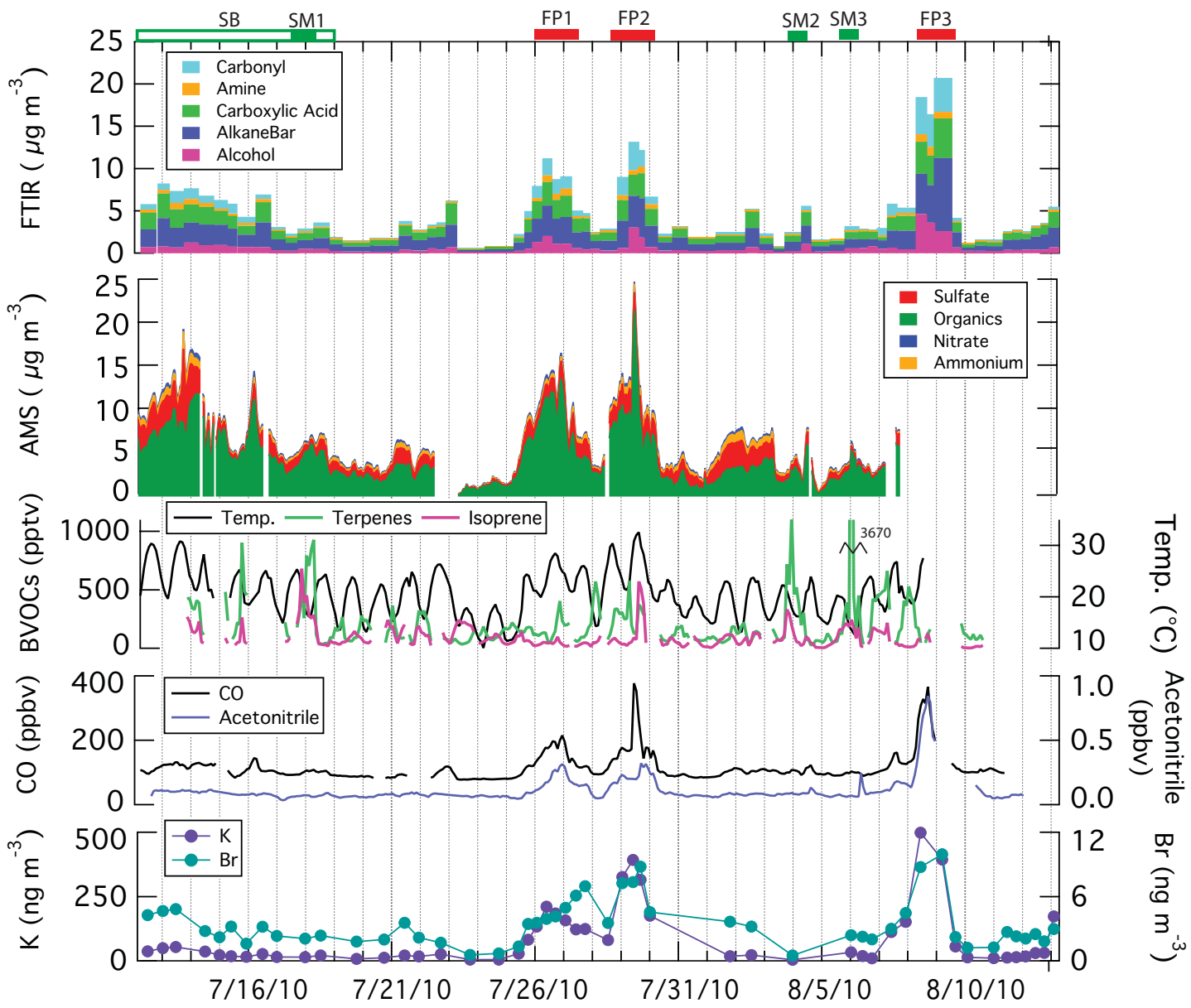

Fig. 1. Time series of submicron aerosol components and gas-phase tracers with stressed boreal (green outline), sawmill (green box) and fire (red box) periods denoted at figure top. (A) Organic functional groups from FTIR, including alcohol (pink), alkane (blue), carboxylic acid (green), amine (orange), and carbonyl (teal). (B) Nonrefractory organic aerosol from C-ToF-AMS including organics (green), sulfate (red), ammonium (orange), and nitrate (blue). (C) $2 \mathrm{~h}$ average sum of monoterpenes (light green), isoprene (pink), and temperature (black). (D) $2 \mathrm{~h}$ average CO (black) and acetonitrile (violet). (E) XRF potassium (purple) and XRF bromine (teal) for subset of FTIR filters analyzed by XRF. Stressed boreal periods were identified by several weeks of unusually high temperatures prior to and during the first week of the campaign (Bäck et al., 2013) and sawmill periods by their enrichment of (+)- $\alpha$-pinene over its $(-)$ - $\alpha$-pinene enantiomer, coinciding with abnormally high nighttime spikes in monoterpene and isoprene concentrations (Williams et al., 2011). Fire periods were defined as times that exhibited acetonitrile, $\mathrm{CO}$, potassium, and bromine concentrations, with percent increases of greater than $100 \%$ above background concentrations.

observed when biomass burning emissions were advected to the field site.

\subsubsection{OM and $\mathrm{O} / \mathrm{C}$ comparison}

FTIR OM and AMS OM showed strong agreement $(r=0.94$, slope $=0.9$ ), with the slight difference between the techniques falling within the FTIR and AMS uncertainties of 20$30 \%$ (Russell et al., 2009a, b) (Fig. S1). Such strong agreement between the two independent techniques provides evidence of the accuracy and completeness of the OM quantification of both methods. Other field campaigns have shown lower correlation between the two methods $(r=0.7)$, likely due to OM contributions by refractory marine and dust particles (Hawkins et al., 2010; Liu et al., 2012), where this difference is consistent with the low AMS collection efficiency for refractory particles (Alfarra et al., 2004; Matthew et al., 2008). The high correlation between the two independent techniques suggests limited semivolatile OM losses from FTIR filters and accuracy of the AMS collection efficiency.

Campaign average $\mathrm{O} / \mathrm{C}_{\mathrm{FTIR}}$ was $0.56 \pm 0.08$, with carboxylic acid (0.31) accounting for $55 \%$ of the total $\mathrm{O} / \mathrm{C}_{\mathrm{FTIR}}$. Sawmill periods were found to have lower $\mathrm{O} / \mathrm{C}_{\mathrm{FTIR}}$ values $(0.50 \pm 0.06)$, while fire periods appeared to be more processed with an average $\mathrm{O} / \mathrm{C}_{\mathrm{FTIR}}$ of $0.67 \pm 0.08$. $\mathrm{O} / \mathrm{C}_{\mathrm{AMS}}$ was slightly greater than $\mathrm{O} / \mathrm{C}_{\mathrm{FTIR}}$, with a campaign average $\mathrm{O} / \mathrm{C}_{\mathrm{AMS}}$ of $0.76 \pm 0.06$. When clean air masses originated over northern Scandinavian boreal forests, O/C $\mathrm{C}_{\mathrm{FTIR}}$ 

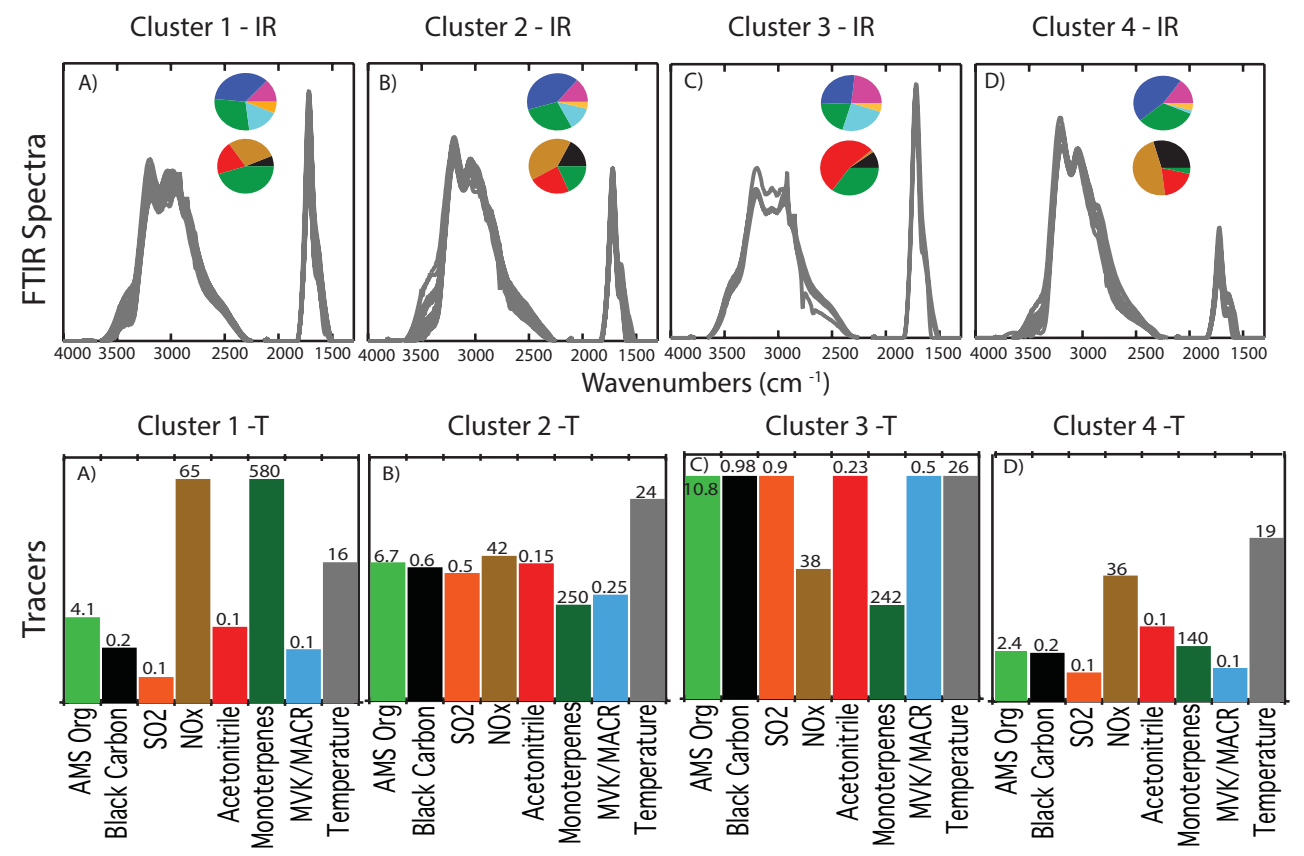

Fig. 2. (Top) FTIR spectral clusters from Ward algorithm (A) Cluster 1 - IR (23 spectra), (B) Cluster 2 - IR (22 spectra), (C) Cluster 3 - IR (5 spectra), and (D) Cluster 4 - IR (11 spectra). Top pie chart in each panel shows average organic functional composition for each cluster: alcohol (pink), alkane (blue), carboxylic acid (green), nonacid carbonyl (teal), and primary amine (orange). Bottom pie chart in each panel represents the average contribution of each FTIR PMF factor in each of the four clusters: FFC1 FTIR (black), FFC2 FTIR (tan),

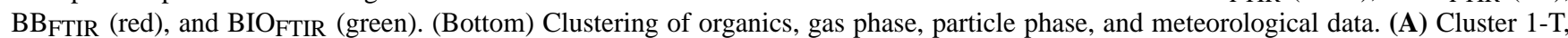
high monoterpenes $(580 \mathrm{ppt})$ and $\mathrm{NO}_{\mathrm{x}}(65 \mathrm{ppb})$. (B) Cluster 2-T, low organics $\left(6.7 \mu \mathrm{g} \mathrm{m}^{-3}\right)$. (C) Cluster 3-T, high organics $\left(10.8 \mu \mathrm{g} \mathrm{m}^{-3}\right)$, $\mathrm{SO}_{2}(0.9 \mathrm{ppb}), \mathrm{MVK} / \mathrm{MACR}(0.5 \mathrm{ppt})$, and temperature $\left(26^{\circ} \mathrm{C}\right)$. (D) Cluster $4-\mathrm{T}$, low organics $\left(2.4 \mu \mathrm{g} \mathrm{m}{ }^{-3}\right)$ and moderate temperatures $\left(19^{\circ} \mathrm{C}\right)$. Cluster averages of each tracer are normalized to the maximum value of each tracer to show relative differences between cluster groups. Average values of each tracer are listed on the bar plot: AMS organics and black carbon $\left(\mu \mathrm{g} \mathrm{m}^{-3}\right), \mathrm{SO}_{2}, \mathrm{NO}_{\mathrm{x}}$, and acetonitrile (ppb), monoterpenes and MVK/MACR (ppt).

was greater than $\mathrm{O} / \mathrm{C}_{\mathrm{AMS}}$. During these times, the FTIRmeasured alcohol functional group accounted for more than $50 \%$ of the $\mathrm{O} / \mathrm{C}_{\mathrm{FTIR}}$, which may be underestimated by the $f_{44}\left(\mathrm{CO}_{2}^{+}\right.$fragment $)$that was used as a proxy for $\mathrm{O} / \mathrm{C}_{\mathrm{AMS}}$. Sawmill periods were found to have lower $\mathrm{O} / \mathrm{C}_{\mathrm{AMS}}$ values of $0.61 \pm 0.13$, while fire periods appeared to be more processed with an average $\mathrm{O} / \mathrm{C}_{\mathrm{AMS}}$ of $0.79 \pm 0.15$. Both methods indicate that the aerosol at Hyytiälä is highly oxidized, with $\mathrm{O} / \mathrm{C}$ ratios greater than 0.4 (DeCarlo et al., 2008). However, despite this general agreement in high and low $\mathrm{O} / \mathrm{C}$ events, there is a low correlation $(r=0.20)$ of $\mathrm{O} / \mathrm{C}$ between the AMS and FTIR methods, which may result from the dependence of $\mathrm{O} / \mathrm{C}$ on fragments other than $\mathrm{m} / \mathrm{z} 44$, as well as other uncertainties in the AMS and FTIR measurements.

\subsection{Source apportionment}

Associating organic particles with their sources is important both for apportioning PM for regulatory purposes and for classifying the type of organic composition. Typically the major contribution to organic mass in populated areas is from fossil fuel combustion (FFC) (which includes both
POA and SOA), primarily from motor vehicles (Liu et al., 2012), with smaller contributions from cooking and residential wood burning (Mohr et al., 2012). However, in forested areas, important seasonal contributions can come from both biogenic emissions and biomass burning events (Slowik et al., 2010; Takahama et al., 2011).

\subsubsection{Clustering of FTIR spectra and organic tracers}

Hierarchical Ward cluster analysis (Ward, 1963) was used to group 65 normalized FTIR spectra into four clusters (Fig. 2). More than four clusters resulted in cluster groups with few spectra $(<4)$. Particles in Cluster 1-IR had the largest fraction of carboxylic acid $(28 \%)$ and the lowest fraction of alcohol groups $(13 \%)$ of the four clusters, with alkane, carbonyl, and amine groups respectively contributing $35 \%, 16 \%$, and $6 \%$ of the OM. Cluster 2-IR was found to have similar OFGs to Cluster 1-IR, but with a higher alkane group fraction (41\%). Spectra of Cluster 3-IR were characterized by strong methylene peaks, but did not have the highest alkane fraction of the clusters. Cluster 3-IR had the largest OM $\left(12.6 \mu \mathrm{g} \mathrm{m}^{-3}\right)$ and the highest $\mathrm{O} / \mathrm{C}(0.68)$, in addition to the largest fractions of alcohol $(23 \%)$ and carbonyl $(25 \%)$ groups. Cluster 


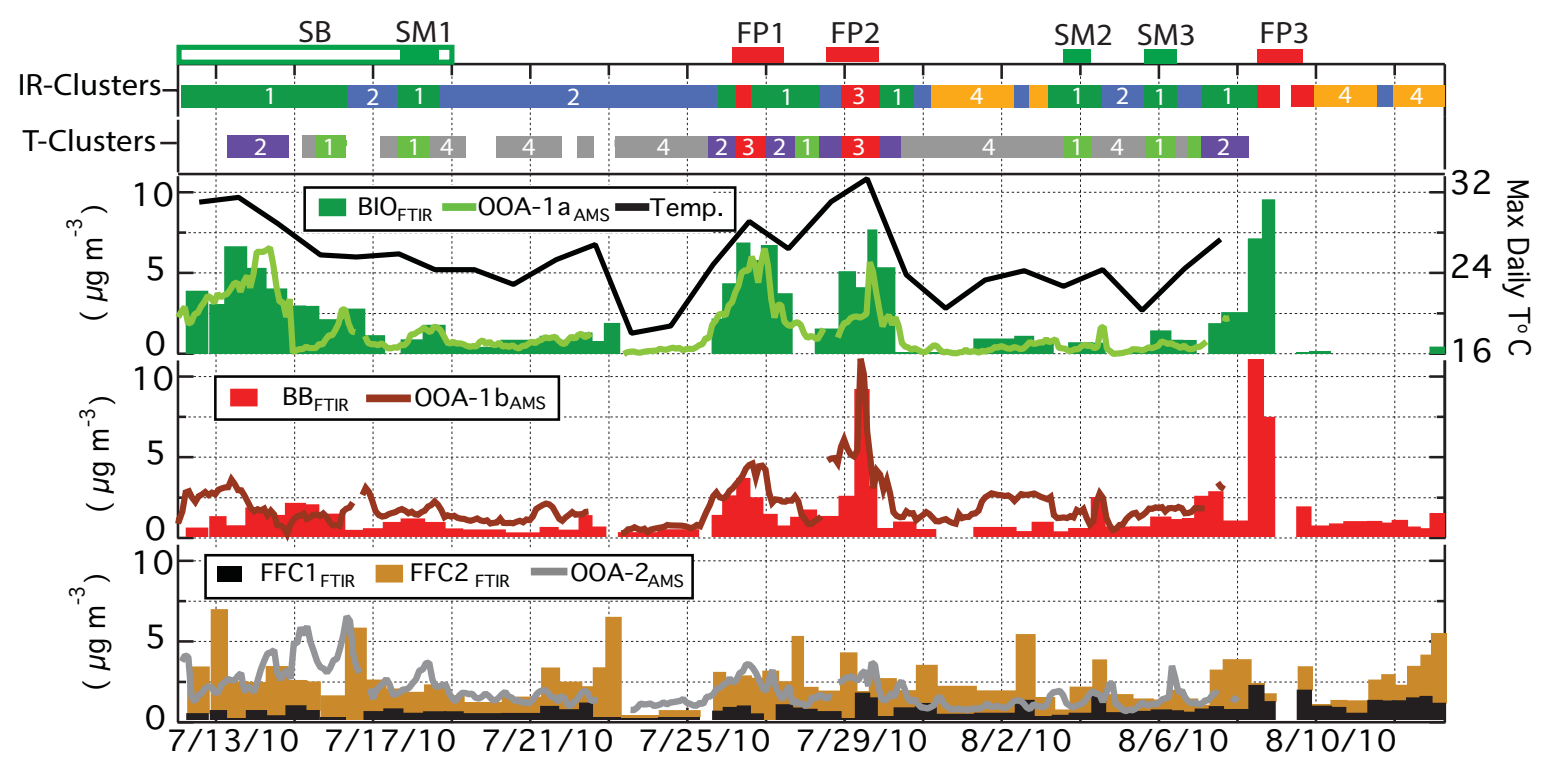

Fig. 3. Time series of submicron OM reconstructed from PMF analysis on AMS and FTIR spectra and clusters of FTIR spectra (IR-Clusters) and tracers (T-Clusters). (Top) Times series of IR-Clusters: Cluster 1-1R (green), Cluster 2-IR (blue), Cluster 3-IR (red), Cluster 4-IR (orange); and T-Clusters: Cluster 1-T (light green), Cluster 2-T (purple), Cluster 3-T (red), and Cluster 4-T (grey). Bars horizontally span sampling periods for each filter (or filter-averaged period). (Bottom) Time series of AMS and FTIR factors grouped by factor source: biogenic (which includes maximum daily temperature), combustion, and biomass burning. Color bars on top of figure indicate periods of stressed boreal conditions (green outline), sawmill (green box), and fire periods (red box).

4-IR particles had the highest alkane group fraction (46\%) and contained the lowest $\mathrm{O} / \mathrm{C}(0.49)$ of the four clusters. Additionally, Cluster 4-IR contained no carbonyl groups and had the lowest overall OM $\left(2.2 \mu \mathrm{g} \mathrm{m}^{-3}\right)$. Spectral signatures of Cluster 4-IR include strong ammonium absorbance, and their spectral profiles closely resemble fossil fuel combustion factors identified at previous field campaigns (Russell et al., 2011). Amine group contributions were $<5 \%$ for all four clusters, consistent with low mass fraction of amines for the entire campaign.

Particle types were also identified by clustering eight selected tracers, including anthropogenic tracers $\left(\mathrm{SO}_{2}, \mathrm{NO}_{\mathrm{x}}\right.$, and black carbon), biogenic tracers (monoterpenes and methylvinylketone/methacrolein, MVK/MACR), sum of organic fragments measured by AMS ("AMS Org"), and temperature (Fig. 2). Tracers were filter-averaged and centered by their root mean square prior to clustering by hierarchical Ward cluster analysis (Ward, 1963). Cluster 1$\mathrm{T}$ had the highest cluster averages for $\mathrm{NO}_{\mathrm{x}}(65 \mathrm{ppb})$ and monoterpenes $(580 \mathrm{ppt})$ and the lowest average temperature $\left(16^{\circ} \mathrm{C}\right)$. Sawmill activity also coincided with Cluster 1-T on the nights of 17 July and 3 and 5 August. Tracer averages in Cluster 2-T were midrange, with the exception of elevated temperatures $\left(24^{\circ} \mathrm{C}\right)$. The average tracer values were the highest in Cluster 3-T, including organic mass $\left(10.8 \mu \mathrm{g} \mathrm{m}^{-3}\right)$, black carbon $\left(0.98 \mu \mathrm{g} \mathrm{m}^{-3}\right), \mathrm{SO}_{2}(0.9 \mathrm{ppb})$, acetonitrile $(0.23 \mathrm{ppb}), \mathrm{MVK} / \mathrm{MACR}(0.5 \mathrm{ppt})$, and temperature $\left(26^{\circ} \mathrm{C}\right)$. Cluster 3-T corresponded to arrival of biomass burning emissions on 26-28 July, 29-30 July, and 8-9 August. The lowest concentrations were observed for nearly all tracers in Cluster 4-T, including organic mass $\left(2.4 \mu \mathrm{g} \mathrm{m}^{-3}\right)$ and monoterpenes (140 ppt). Organic mass in Cluster 3-T and monoterpene concentrations in Cluster 1-T were nearly 5 times greater than those in Cluster 4-T.

Overall the groupings in the FTIR-based and tracer-based clusters were consistent, in that both identified overlapping periods of low-OM biogenics (Cluster 1-IR and 1-T) and high-OM biogenics from periods of biomass burning (Cluster 3-IR and 3-T) (Fig. 3). The tracer clusters were influenced by short-duration source events, specifically sawmill activity (Cluster 1-T) and biomass burning (Cluster 3-T). Although a biomass burning IR cluster was identified (Cluster 3-IR), sawmill activity was not identified by FTIR cluster analysis and instead grouped with the low-OM biogenics of Cluster 1-IR. This is likely due to the spectral uniqueness of biomass burning OM (strong methylene signature) and the spectral similarity seen between sawmill events and other biogenically enhanced periods (i.e. stressed boreal conditions exhibited during the first week of the campaign; Bäck et al., 2013). In addition, the higher time resolution of the AMS was better suited to capture the chemical signatures of the short-lived sawmill events than the lower time resolution of FTIR. Additionally, Cluster 2-T with elevated OM, MVK/MACR, and temperature occurred simultaneously with Cluster 1-IR, which is dominated by biogenic organic aerosol (see Sect. 3.2.2 for more details). FTIR-based 

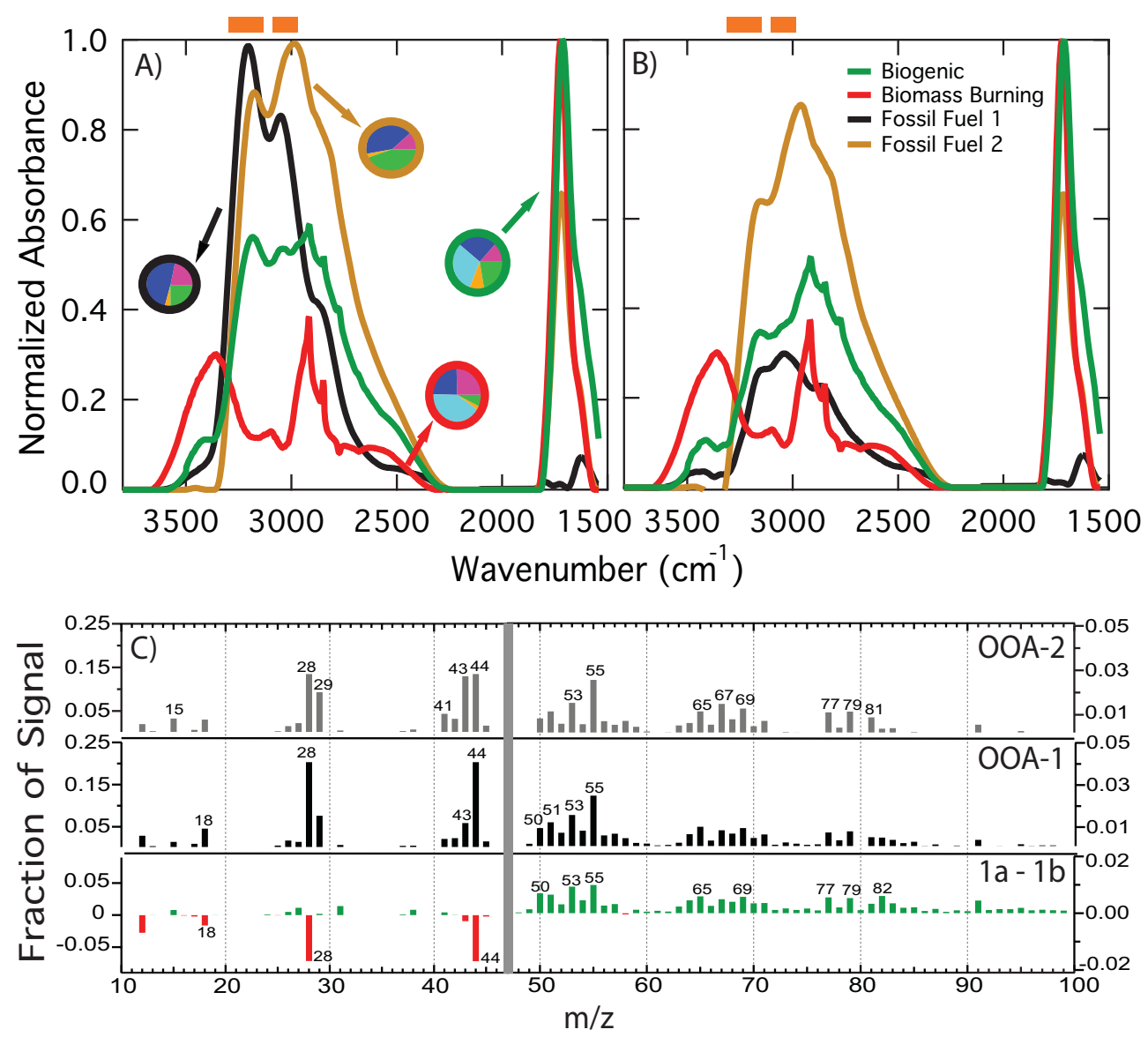

Fig. 4. Normalized FTIR and AMS spectra from the 4-factor $(F P E A K=0$, seed $=1)$ and 3 -factor $(F P E A K=-0.4$, seed $=1)$ PMF solutions. (A) FTIR factors: FFC1 $1_{\text {FTIR (black), FFC2 }}$ FTIR (tan), $\mathrm{BB}_{\mathrm{FTIR}}$ (red), and $\mathrm{BIO}_{\mathrm{FTIR}}$ (green). Pies show average organic functional group composition for each factor: alkane (blue), alcohol (pink), amine (orange), carbonyl (teal), and carboxylic acid (green). Factor spectra include organics and ammonium. (B) FTIR factor spectra after subtraction of ammonium absorbance so that only organic absorbance is shown (factors were smoothed by a 5-point box algorithm). Orange bars on top denote region of ammonium absorbance. (C) Normalized mass spectra for the 3-factor PMF solution: OOA-1 AMS, OOA-2 AMS, and the difference mass spectra of OOA-1aAMS and OOA-1b $\mathrm{AMS}$. Vertical grey bar indicates change in axis for fragments greater than $m / z 47$.

clusters did identify different clusters for high ammonium (Cluster 4-IR) and low ammonium (Cluster 2-IR) concentrations associated with two kinds of fossil-fuel-combustionlike spectra, but the tracer-based cluster (Cluster 4-T with low OM and tracer concentrations) grouped these high ammonium and low ammonium periods together (Fig. 3).

\subsubsection{Factors identified by FTIR measurements}

PMF (Paatero and Tapper, 1994) was applied to FTIR spectra to identify organic mass sources. Details of PMF procedures are described in the Supplement. FTIR factors were identified with sources by their temporal correlations to tracers and reference standards, as well as their spectral similarity to factors from previous campaigns (Russell et al., 2011). Figure $4 \mathrm{a}$ and $\mathrm{b}$ show the four-factor solutions identified from FTIR measurements. The first factor contains strong ammonium absorbance (3050 and $3200 \mathrm{~cm}^{-1}$ ), which was also found in anthropogenic combustion factors identified in past campaigns, and is identified as Fossil Fuel Combustion 1 (FFC1 $1_{\text {FTIR }}$ ) (Hawkins et al., 2010; Liu et al., 2012; Russell et al., 2011). The factor was also dominated by alkane groups (49\%) and lacked carbonyl groups (Table 3 ). FFC1 $1_{\text {FTIR }}$ also had the lowest $\mathrm{O} / \mathrm{C}$ of the factors $(0.14)$, consistent with previously reported FFC factors (Russell et al., 2011). The factor varied in time with moderate correlations $(0.50<r<0.75)$ to $\mathrm{XRF} \mathrm{V}$ and $\mathrm{Zn}$ ( $r$ of 0.5 and 0.6 , respectively), as well as to butane $(r=0.5)$, indicating an association with combustion or industrial processes (Fig. S4). Overall, FFC1 $1_{\text {FTIR }}$ represented a small fraction of the reconstructed OM at Hyytiälä (12\%, $\left.0.6 \mu \mathrm{g} \mathrm{m}^{-3}\right)$. FFC1 $1_{\text {FTIR }}$ had the largest contribution $(27 \%)$ to Cluster 4-IR particles, as indicated by the strong ammonium contribution in this cluster (Fig. 2).

The second factor is strongly dominated by alkane (41\%) and carboxylic acid (45\%) functional groups and 
Table 3. Summary of concentration, OM fraction (shown in parentheses), O/C, and composition (organic functional group composition of FTIR factors and prevalent $m / z$ signatures of AMS factors) for FTIR and AMS factors. Organic functional groups from FTIR, including alcohol (pink), alkane (blue), carboxylic acid (green), amine (orange), and carbonyl (teal).

\begin{tabular}{|c|c|c|c|}
\hline Factor & Campaign avg. $\left(\mu \mathrm{g} \mathrm{m}^{-3}\right)$ & $\mathrm{O} / \mathrm{C}$ & Composition \\
\hline $\mathrm{BOA}_{\mathrm{FTIR}}$ & $1.7(35 \%)$ & 0.75 & \\
\hline $\mathrm{BB}_{\mathrm{FTIR}}$ & $1.2(25 \%)$ & 0.53 & \\
\hline FFC1 $1_{\text {FTIR }}$ & $0.6(12 \%)$ & 0.14 & \\
\hline FFC2FTIR & $1.3(27 \%)$ & 0.27 & \\
\hline OOA- 1 AMS & $3.0(70 \%)$ & 0.87 & $m / z: 28,44,50,51,53,55,65,69$ \\
\hline OOA-1a & $1.3(30 \%)$ & 0.71 & $m / z: 50,53,55$ \\
\hline OOA-1b & $1.7(39 \%)$ & 0.99 & $m / z: 44,28,18$ \\
\hline OOA-2AMS & $1.3(30 \%)$ & 0.60 & $m / z: 41,43,55,67$ \\
\hline
\end{tabular}

corresponded to $27 \%\left(1.3 \mu \mathrm{g} \mathrm{m}^{-3}\right)$ of the reconstructed $\mathrm{OM}$ (Table 3). The time series is correlated moderately with AMS sulfate $(r=0.6)$ and weakly $(0.25<r<0.50)$ with black carbon $(r=0.3)$, and found no correlation $(-0.25<r<0.25)$ with FFC1 $1_{\text {FTIR }}(r=-0.2)$. The correlation with sulfate and black carbon is consistent with a fossil fuel combustion source for this factor, which is named Fossil Fuel Combustion 2 (FFC2 $\left.2_{\mathrm{FTIR}}\right)$. This second fossil fuel factor showed lower ammonium absorbance than $\mathrm{FFC1} 1_{\mathrm{FTIR}}$, and its $\mathrm{O} / \mathrm{C}$ was nearly twice $(0.27)$ that of FFC1 1 FTIR $(0.14)$. Since FFC2 $2_{\text {FTIR }}$ was not correlated with FFC1 $_{\text {FTIR }}$ and was correlated with a different set of combustion-related tracers, this factor likely represents a regional source of fossil fuel combustion emissions that have undergone atmospheric processing. FFC2 2 FTIR had substantial contributions (45\% and $47 \%$ ) to Cluster 2-IR and Cluster 4-IR particles (Fig. 2). Both clusters included high ammonium and alkane group absorbance, similar to FFC2 2 FTIR.

Factor 3 accounted for $25 \%$ of the campaign OM and consisted largely of oxygen-containing OFG (O-OFG): carbonyl (41\%), alcohol (25\%), and carboxylic acid (9\%) groups, with an $\mathrm{O} / \mathrm{C}$ of 0.53 (Table 3). The overall spectral shape and composition is remarkably similar to biomass burning factors identified previously by Hawkins and Russell (2010) and Takahama et al. (2011), which are characterized by a broad, multipeaked absorbance in the $2800-3300 \mathrm{~cm}^{-1}$ region and are shown in Fig. 7. This factor correlates strongly $(r>0.75)$ with biomass burning tracers $\mathrm{CO}(r=0.9)$, acetonitrile $(r=0.8), \mathrm{K}(r=0.8)$, and moderately to $\mathrm{Br}(r=0.7)$ (Andreae, 1983; Crutzen and Andreae, 1990; Holzinger et al., 1999). Because of these strong correlations with tracers of biomass burning, spectral similarities to biomass burning FTIR factors identified in other projects, and the high contributions of this factor to OM during fire periods (Fig. 3), Factor 3 is identified as Biomass Burning (BB $\left.\mathrm{BB}_{\mathrm{FTIR}}\right)$. $\mathrm{BB}_{\mathrm{FTIR}}$ contributed $55 \%$ of the OM in Cluster 3-IR particles (Fig. 2), which occurred primarily during biomass burning periods (Fig. 3).

The $\mathrm{BB}_{\mathrm{FTIR}}$ spectra contains strong absorbance in the alkane region at $2920 \mathrm{~cm}^{-1}$ and $2850 \mathrm{~cm}^{-1}$, similar to the spectra reported for biomass burning emissions transported from central California wildfires and illustrated in Fig. 4 (Hawkins and Russell, 2010). This pair of peaks is associated with repeated methylene groups, as are found in long-chain plant cuticle waxes and other detritus (Hawkins and Russell, 2010). $B_{\text {FTIR }}$ had a higher fraction of alcohol groups than previously reported for similar measurements of biomass burning OM (Russell et al., 2011), which could be from higher contribution of resuspended vegetative detritus either associated with the wildfires or from local forests. The high mass fraction of alcohol groups is consistent with the composition of lignin and other carbohydrates in vegetative material (Bianchi et al., 1993; Cass, 1998) and with reported submicron $\mathrm{OM}$ from vegetative detritus resuspended with dust particles (with correlations with $\mathrm{Al}, \mathrm{Si}, \mathrm{Ca}$, and $\mathrm{Fe}$ ) (Ahlm et al., 2013; Liu et al., 2012). BB FTIR correlated moderately with XRF dust elements $\mathrm{Si}(r=0.5), \mathrm{Fe}(r=0.5)$, and metal oxides $(r=0.5)$. However, since hot and dry conditions prevailed both locally and in the wildfires, either the wildfires or the local forests could account for the vegetative detritus contribution. 
The fourth factor was the most oxygenated factor $(\mathrm{O} / \mathrm{C}=0.75)$, with carbonyl and carboxylic acid functional groups representing $29 \%$ and $22 \%$ of the OM, respectively (Table 3). The relative contributions of these O-OFG and the FTIR spectral shape are similar to the biogenic aerosol identified previously in other boreal forests (Ahlm et al., 2013; Schwartz et al., 2010; Takahama et al., 2011), as illustrated in Fig. 7. Factor 4 correlated strongly with several PTR-MS gas-phase organic secondary compounds with long lifetimes (1-3 weeks), including acetone $(r=0.9)$, methanol $(r=0.9)$, and acetic acid $(r=0.8)$ and to shorter-lived BVOC oxidation products MVK/MACR ( $r=0.9)$ (Fig. S4). In addition, Factor 4 correlated strongly with monoterpene oxidation products measured by PTR-MS, pinonaldehyde $(m / z$ 99, $r=0.9)$ (Wisthaler et al., 2001), a monoterpene oxidation fragment ( $m / z$ 113, $r=0.8$ ) (Lee et al., 2006), and moderately with APCI-MS particle-phase cis-pinic acid $(m / z 185, r=0.7)$ (Vogel et al., 2013). Factor 4 was also moderately correlated with temperature $(r=0.7)$, likely since several BVOC emissions increase with temperature as they are volatilized from storage pools in the needles (Guenther et al., 1993). Prior to the campaign, the boreal forest was impacted by several weeks of unusually high temperatures above $30^{\circ} \mathrm{C}$, causing heat stress to the forest (Bäck et al., 2013). The period of heat stress extended into the first week of the campaign (1219 July), which coincided with the second-highest maximum temperature of the campaign $\left(30.8^{\circ} \mathrm{C}\right)$. During this time, Factor 4 was the dominant source of OM (Fig. 3). Therefore, this factor is identified as biogenic SOA (BIOFTIR), which accounted for $35 \%$ of OM throughout the campaign, with an average concentration of $1.7 \mu \mathrm{g} \mathrm{m}^{-3}$.

The time series of contributions of BIO FTIR and BB $_{\text {FTIR }}$ were moderately correlated with each other $(r=0.5)$, but this correlation results from the coincidence of elevated concentrations of both $\mathrm{BIO}_{\mathrm{FTIR}}$ and $\mathrm{BB}_{\mathrm{FTIR}}$ during the fire periods as they were also the hotter periods (Fig. 3). The absence of $\mathrm{BB}_{\mathrm{FTIR}}$ during the part of the project without fire influence indicates that this is not because the similarity in the O-OFG composition of BIO and BB caused OM to be misapportioned by PMF. Instead the increase in the BIO during the fire periods is likely the result of enhanced BVOCs during the hot and dry conditions that accompanied the fire periods (Greenberg et al., 2006; Yokelson et al., 1996). Moreover, the chemical similarity of the O-OFG compositions of the two factors is not surprising, since both factors are expected to include secondary organic aerosol components from monoterpenes and other BVOCs. In particular, boreal forest fire plumes have substantial amounts of monoterpenes, with concentrations reaching 40 times greater than background mixing ratios (Simpson et al., 2011). The monoterpenes are distilled from vegetative oil reservoirs during the fire, but not all are oxidized in the flame. The presence of monoterpenes in fire plumes also explains the moderate correlation of $\mathrm{BB}_{\mathrm{FTIR}}$ with $\mathrm{BVOC}$ oxidation products MVK/MACR ( $r=0.7)$ (Fig. S4).
Similar to fossil fuel combustion factors in other regions (Russell et al., 2011), FFC1 $1_{\text {FTIR }}$ contained most of the measured ammonium absorbance, followed by FFC2 $2_{\text {FTIR, }}$ reinforcing the distinct separation of the two fossil fuel combustion sources. BIOFTIR factor contained some ammonium absorbance. The attribution of ammonium to the $\mathrm{BIO}_{\mathrm{FTIR}}$ factor is likely from nearby agricultural activities (including animal waste and soil fertilizer), as they are responsible for up to $90 \%$ of the ammonia emissions in Finland (Grönroos et al., 2009). In order to compare organic functional groups in each factor, ammonium absorbance was removed from the factor spectra by scaling an ammonium sulfate reference spectrum to the absorbance at $3238 \mathrm{~cm}^{-1}$ and subtracting it from the baselined spectrum (Fig. 4b). The subtracted spectra illustrate the higher alcohol group absorbance by FFC2 and the difference in the alkane group absorbance.

\subsubsection{Factors identified by AMS measurements}

Three factors were identified from the AMS measurements. The 3-factor solution reconstructed $98 \%$ of measured OM, with time series and normalized spectra of the AMS factors shown in Figs. 3 and 4c, with details of the PMF procedures given in the Supplement.

The first factor had an $\mathrm{O} / \mathrm{C}$ ratio of 0.71 (estimated by the approximation given by Aiken et al. (2008)) and had prominent fragments at $m / z 29\left(\mathrm{CHO}^{+}\right)$and $m / z 43\left(\mathrm{C}_{2} \mathrm{H}_{3} \mathrm{O}^{+}\right)$. The fragments are consistent with $\alpha$-pinene SOA from chamber experiments and biogenic SOA from plant chamber studies (Chhabra et al., 2011; Kiendler-Scharr et al., 2009; Shilling et al., 2009). The factor strength correlated moderately with temperature $(r=0.6)$, strongly with BVOC oxidation products (MVK/MACR) $(r=0.8)$, and strongly with numerous PTR-MS gas-phase organic compounds including acetone $(r=0.9)$, methanol $(r=0.8)$, and acetic acid $(r=$ 0.8 ) (Fig. S5). The factor correlated strongly with monoterpene oxidation products measured by PTR-MS and APCIMS, including pinonaldehyde $(m / z 99, r=0.8)$, monoterpene oxidation fragment $(m / z 113, r=0.8)$, and cis-pinic acid $(m / z 185, r=0.6)$. The time series of this factor peaked during sawmill events (early morning of 17 July, 4 August, and 6 August), consistent with this sporadic influence of biogenic-like SOA (Fig. 3). Additionally the factor was prominent during the first week of the campaign (1219 July), when the local forests were undergoing a period of heat stress (Fig. 1). The factor also correlated strongly with $\mathrm{BIO}_{\mathrm{FTIR}}(r=0.9)$. Slowik et al. (2010) reported a factor $(\mathrm{O} / \mathrm{C}=0.46)$ identified in Egbert, Canada, that was associated with biogenic organic aerosol; however, the Egbert factor did contain a higher fraction of $m / z$ 43. Previous springtime measurements at Hyytiälä have identified similar factors (OOA-2), but with much lower O/C (0.22 and 0.23), indicating these factors had undergone less atmospheric processing (Finessi et al., 2012; Raatikainen et al., 2010). Due to the correlation with $\mathrm{MVK} / \mathrm{MACR}$ and $\mathrm{BIO}_{\mathrm{FTIR}}$, Factor 1 is referred 
to as OOA-1aAMs, which likely has a strong biogenic influence.

The second factor was found to be the most oxidized of the three factors, with $\mathrm{O} / \mathrm{C}$ ratio of 0.99 and $f_{44}$ of 0.24 . Factor 2 was spectrally similar to OOA-1aAMs (Fig. 4c); however, it contained a higher $f_{44}$-to- $f_{43}$ ratio (4.0) than OOA-1aAMs (3.15), suggesting a more oxygenated organic aerosol (Ng et al., 2010). The time series of Factor 2 correlated strongly with biomass burning emission tracers: $\mathrm{K}$ $(r=0.9), \mathrm{Br}(r=0.8)$, acetonitrile $(r=0.7), \mathrm{CO}(r=0.9)$, and $\mathrm{BC}(r=0.9)$, in addition to $\mathrm{Pb}(r=0.9)$ (Fig. S5). Due to the association with biomass burning emission tracers, high $\mathrm{O} / \mathrm{C}$ value, and similar fragmentation pattern as OOA-1a $\mathrm{a}_{\mathrm{AMS}}$, the second factor is identified as OOA- $1 \mathrm{~b}_{\mathrm{AMS}}$.

The OOA- $1 b_{A M S}$ mass spectrum is chemically indistinguishable from OOA-1 $\mathrm{a}_{\mathrm{AMS}}$, except that OOA-1 $\mathrm{b}_{\mathrm{AMS}}$ has a larger $m / z 44$ signal and smaller signals for $m / z>51$ (Fig. 4c). OOA-1 $\mathrm{a}_{\mathrm{AMS}}$ and OOA-1b $1 \mathrm{~b}_{\mathrm{AMS}}$ factors were moderately correlated in time $(r=0.6)$, and OOA- $1 b_{\text {AMS }}$ had highest concentrations during the FP1 and FP2 fire periods (Fig. 3) and correlated strongly with $\mathrm{BB}_{\mathrm{FTIR}}(r=0.8)$. Without biomass burning tracers $(\mathrm{CO}$, acetonitrile, $\mathrm{K}, \mathrm{Br})$ that had clear time series correlations with the factor, OOA- $1 b_{\text {AMS }}$ could not have been distinguished from OOA-1aAms. However, PMF factors have substantial uncertainty, especially when the chemical characteristics and time series have significant overlap. For this reason, we also present the same solution with the two similar factors (OOA-1a and OOA1b) combined together in a factor named OOA-1, which was found to correlate strongly $(r>0.8)$ with both biogenic and biomass burning tracers and accounted for $70 \%$ of the reconstructed OM (3.0 $\left.\mu \mathrm{g} \mathrm{m}^{-3}\right)$ (Fig. S5).

Tracers of BBOA have also included enhanced signals of levoglucosan mass fragments $m / z 57\left(\mathrm{C}_{4} \mathrm{H}_{9}^{+}\right.$or $\left.\mathrm{C}_{3} \mathrm{H}_{5} \mathrm{O}^{+}\right)$, $m / z 60\left(\mathrm{C}_{2} \mathrm{H}_{4} \mathrm{O}_{2}^{+}\right)$, and $m / z 73\left(\mathrm{C}_{3} \mathrm{H}_{5} \mathrm{O}_{2}^{+}\right)$in AMS spectra (Lee et al., 2010; Schneider et al., 2006). Specifically levoglucosan $(m / z 60)$ is formed during the pyrolysis of cellulose and has been a useful tracer for identifying biomass burning plumes (Cubison et al., 2011). However, $\mathrm{O}_{-B_{B O A}}$ AMS and AMS measurements during fire periods were found to have $f_{60}$ near background levels $(0.3 \%)(\mathrm{Cu}-$ bison et al., 2011). The absence of levoglucosan tracers in

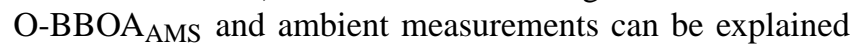
by photochemical degradation, as back trajectory analysis suggests biomass burning emissions underwent 4-5 days of atmospheric processing before arriving at Hyytiälä. However, the atmospheric lifetime of levoglucosan is uncertain, as chamber studies have estimated on the order of 0.5-10 days (Hennigan et al., 2010; Hoffmann et al., 2010; Kessler et al., 2010). Additionally fuel types and burn conditions can drastically affect levoglucosan emissions (Engling et al., 2006).

The third factor is the least oxygenated of the three factors, based on its lower $f_{44}$ of 0.17 . However, the factor still has a relatively high $\mathrm{O} / \mathrm{C}$ ratio of 0.60 . The factor has a high frac- tion of $m / z 44$ and fractions of $m / z 43,55$, and 67 fragments that are typical of less oxygenated organic aerosol (OOA-2) factors (Lanz et al., 2007; Sun et al., 2011; Ulbrich et al., 2009). The mass spectrum resembles OOA-2 factors identified at other sites, including Pittsburgh $(r=0.95)$ (Ulbrich et al., 2009; Zhang et al., 2005), and is therefore labeled OOA- 2 AMS. The OOA- 2 AMS factor correlated moderately with AMS nitrate $(r=0.6)$, in addition to a strong correlation with isopentane $(r=0.7)$ (Fig. S5). These correlations with nitrate and isopentane, in addition to the factor $\mathrm{O} / \mathrm{C}$ above 0.2 and below 0.5 , are consistent with compositions previously identified as OOA-2 or semivolatile (SV-OOA) (Lanz et al., 2007; $\mathrm{Ng}$ et al., 2010, 2011b; Sun et al., 2011; Ulbrich et al., 2009; Zhang et al., 2011).

The relationship between $f 44$ and $f_{44}$ (shown in Fig. S7) also reveals no significant differences between OOA-1a and low-volatility oxidized organic aerosol (LV-OOA) (Ng et al., 2011a). However, the three AMS factors do clearly bound all of the AMS measurements in $f_{44}$ and $f_{43}$ space ( $\mathrm{Ng}$ et al., 2011a; Zhang et al., 2011).

\subsubsection{Comparison of FTIR and AMS factors}

The factors identified from AMS measurements are largely consistent with those from FTIR factors, in terms of both chemical speciation and temporal trends. OOA-1aAMs and $\mathrm{BIO}_{\mathrm{FTIR}}$ factors were strongly correlated with each other $(r=0.9)$. Both BIOFTIR and OOA-1 $\mathrm{a}_{\mathrm{AMS}}$ had the largest concentrations during the stressed boreal and fire periods (as described in Sect. 3.2.2); however, OOA-1 $\mathrm{a}_{\mathrm{AMS}}$ was able to capture the sawmill events, as seen in the sawmill periods and those identified by Cluster 1-T shown in Fig. 3. This difference illustrates the ability of the higher time resolution of the AMS measurements to identify local sources (i.e. fresh biogenic OA from sawmill events). The $\mathrm{O} / \mathrm{C}$ ratios of the two biogenic factors were both quite high relative to other reported ambient factors (Jimenez et al., 2009; Russell et al., 2011), with $\mathrm{BIO}_{\mathrm{FTIR}}$ and OOA-1aAMS having $\mathrm{O} / \mathrm{C}$ ratios of 0.75 and 0.71 , respectively (Table 3 ).

To compare the sources of the OOA- $1 \mathrm{a}_{\mathrm{AMS}}$ and $\mathrm{BIO}_{\mathrm{FTIR}}$ factors, PSCF was calculated for the mass fraction of each factor (Pekney et al., 2006; Russell et al., 2009b) and contours representing the potential source region of each factor were plotted over the European geographic distribution of vegetative biomes (Fig. 5a). Potential source regions of both OOA-1 $\mathrm{a}_{\mathrm{AMS}}$ and $\mathrm{BIO}_{\mathrm{FTIR}}$ mass fractions overlap large regions of the Scandinavian boreal forests (Fig. 5a). Both BIOFTIR and OOA-1aAMs factors have large components from the southeast of Finland. This is consistent with BIO $_{\text {FTIR }}$ and OOA-1a $\mathrm{a}_{\mathrm{AMS}}$ having moderate correlations with temperature ( $r=0.7$ and 0.6 , respectively), as temperatures were the highest when air masses arrived from the southeast, similar to the findings of Leaitch et al. (2011) that submicron biogenic organic mass in Whistler, Canada, increased exponentially with temperature. Figure 5 a indicates 

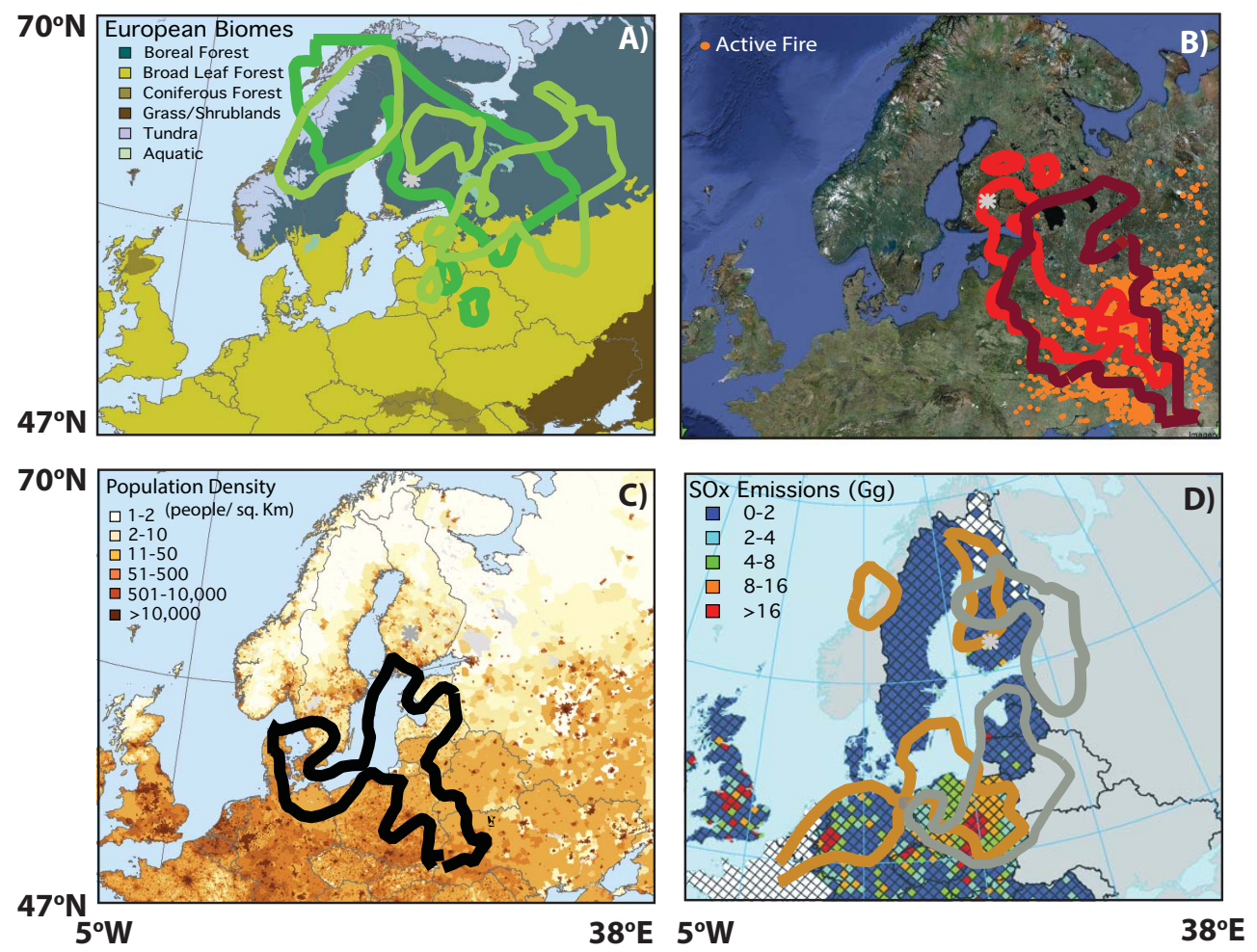

Fig. 5. PSCF of AMS and FTIR factor fractions with contours indicating 0.4 probability of potential source region in each map.

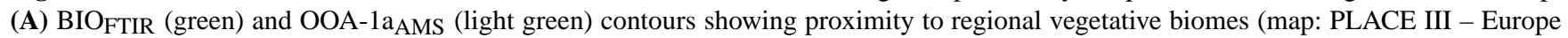
Biomes, http://sedac.ciesin.columbia.edu/data/set/nagdc-population-landscape-climate-estimates-v3). (B) BB FTIR $_{\text {(red) and OOA-1b }}$ AMS (dark red) contours and active wildfire hotspots (12 July-12 August 2010) in eastern Europe and Russia, for fires with $>90 \%$ confidence (fire data: NASA FIRMS, 2012. MODIS active fire detections. Available online https://earthdata.nasa.gov/FIRMS). (C) FFC1 $1_{\text {FTIR }}$ (black) contours and population density for Europe and western Russia (map: PLACE III - Population Density 2010, Europe, http: //sedac.ciesin.columbia.edu/data/set/nagdc-population-landscape-climate-estimates-v3). (D) FFC2 FTIR (brown) and OOA-2 AMS (grey) contours with $2005 \mathrm{SO}_{\mathrm{x}}$ emissions (no-SO $\mathrm{SO}_{\mathrm{x}}$ data are shown in white, and grey regions indicate outside of the study area) (map: EEA, www.eea.europa.eu/data-and-maps/figures/emissions-of-sox-in-2005). Hyytiälä is denoted by a grey asterisk in each map.

that both factors represent contributions from large regional forest biomes.

Photochemical processing of biomass burning plumes can modify the chemical composition of submicron OM. AMS measurements with unit mass resolution (UMR) result in biomass burning mass spectra that look chemically similar to OOA after photochemical processing in the atmosphere (Grieshop et al., 2009). HYSPLIT back trajectories, in addition to fire hotspot locations from FIRMS (fire hotspot data with $>90 \%$ confidence: NASA FIRMS, 2012. MODIS active fire detections; available online https://earthdata.nasa. gov/FIRMS), indicated the biomass burning emissions had been transported more than 4 days prior to their arrival at Hyytiälä. OOA-1 $\mathrm{b}_{\mathrm{AMS}}$ had negligible contributions from levoglucosan mass fragments, $m / z 57,60$, and 73 , likely resulting from the extensive transport time of the plume (Lee et al., 2010; Schneider et al., 2006).

OOA- $1 \mathrm{~b}_{\mathrm{AMS}}$ and $\mathrm{BB}_{\mathrm{FTIR}}$ accounted for $39 \%$ and $25 \%$ of the OM (Table 3). PSCF calculated for mass fractions of OOA- $1 \mathrm{~b}_{\mathrm{AMS}}$ and $\mathrm{BB}_{\mathrm{FTIR}}$ indicate similar source regions for these two factors (Fig. 5b), overlapping in the regions heavily influenced by wildfires near Moscow and Ukraine in July and August 2010. Wildfire hotspots from 12 July to 12 August 2010 are nearly overlapped by the potential source regions of both biomass burning factors.

FFC2 $2_{\text {FTIR }}$ had a weak correlation with OOA-2 2 AMS $(r=0.4)$ and showed geographic overlap in the potential source regions (Fig. 5d). FFC2 $2_{\text {FTIR }}$ was found to have potential source regions near high $\mathrm{SO}_{\mathrm{x}}\left(\mathrm{SO}_{2}+\mathrm{SO}_{3}\right)$ emitting regions, specifically in Germany and Poland. The PSCF of OOA- $2_{\mathrm{AMS}}$ also depicted OOA-2 $2_{\mathrm{AMS}}$ originated near high $\mathrm{SO}_{\mathrm{x}}$ emitting regions, in addition to northwestern Russia, which has significant industrial activity (Hole et al., 2009; Mira-Salama et al., 2008). OOA-2 AMs was found to have no correlation $(r=-0.1)$ to $\mathrm{FFC1}_{\mathrm{FTIR}}$, which represents only a small OM contribution $(12 \%)$. FFC1 $1_{\text {FTIR }}$, which was correlated with $\mathrm{Zn}$ and $\mathrm{V}$, had a small potential source region on the southern coastline of the Baltic Sea in moderately populated regions of Europe (Fig. 5c). 


\section{Discussion of biomass burning and biogenic organic aerosol}

Comparison of the biogenic and biomass burning factors for Hyytiälä OM measurements shows similarities in their composition (as measured by both AMS and FTIR), which are an expected consequence of their similar biological source material (Ahlm et al., 2013; Russell et al., 2011; Schwartz et al., 2010; Takahama et al., 2011): both biomass burning and biogenic OA can contain cellular material, rich in saccharide compounds, that is lofted into the atmosphere and is typically rich in alcohol functional groups (Ahlm et al., 2013; Hawkins and Russell, 2010; Takahama et al., 2011). Both biogenic and biomass burning emissions include similar alkene VOCs that serve as SOA precursors, including monoterpenes, isoprene, and sesquiterpenes (Greenberg et al., 2006; Guenther et al., 1995; Simpson et al., 2011). Therefore they also contain similar oxidation products that are rich in O-OFG. Given these chemical similarities, is it possible to distinguish these two types of OM? Comparing the two techniques for measuring $\mathrm{OM}$, we see that FTIR factor analysis is more sensitive to the small chemical differences between biogenic and biomass burning organic components, while AMS factor analysis has higher time resolution to allow identification of short-term events (such as local sawmill activities).

The fragmentation of organic aerosol in the AMS results in the majority of the organic mass fragments being associated with masses less than $m / z 45$, most of which have less than 2 carbons per fragment. For highly oxidized organic aerosol, the large fraction of $m / z 44$ outweighs the contributions of fragments that are more characteristic of their sources ( $\mathrm{Ng}$ et al., 2011a). For example, in rural regions like Hyytiälä, more than $90 \%$ of OM can be highly oxygenated, making OOA the factor that accounts for a majority of OM in AMS factor analysis (Zhang et al., 2007). One key feature of AMS spectra is that, as OM becomes increasingly photochemically processed, the OM mass fragment fractions converge at a highly oxidized composition regardless of the OM source type (Ng et al., 2011a). Recent measurements at a rural site in the Mediterranean illustrated the consequences of this for separating two OOA AMS factors (OOA-1 and OOA-2) that had very similar mass fragments (Hildebrandt et al., 2010). The small chemical differences between oxidized OM from multiple sources could not be distinguished in the absence of the gas-phase and particle-phase tracers. Because the FTIR factors are spectrally distinct, multiple oxidized OM sources can often be separated chemically in the absence of tracers (Frossard et al., 2011; Hawkins and Russell, 2010; Liu et al., 2012). While the AMS spectra of OOA-1aAMs and OOA$1 b_{\text {AMS }}$ factors at Hyytiälä were very similar (Fig. 4c) (as with the OOA-1 and OOA-2 measured at Crete), the comprehensive suite of gas-phase and particle-phase tracers available during HUMPPA-COPEC made it possible to separate two sources of oxidized OA in the AMS measurements. Without such tracers, the strong chemical similarities between OOA-

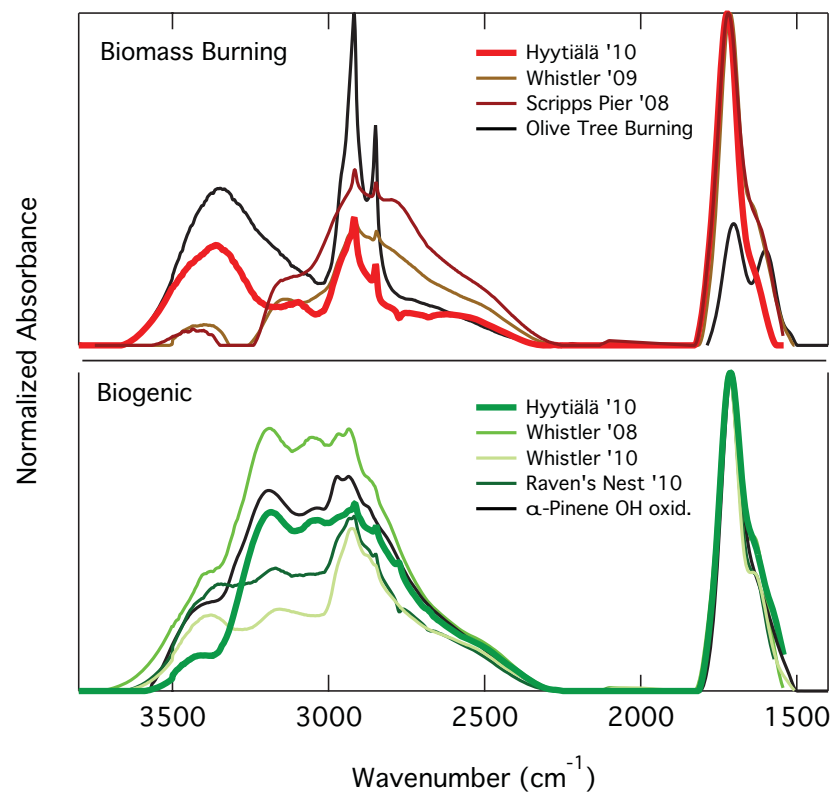

Fig. 6. Normalized biomass burning (top) and biogenic factors (bottom) from Whistler, Canada, and Scripps Pier (La Jolla, CA) (Schwartz et al., 2010; Takahama et al., 2011; Ahlm et al., 2012; Hawkins and Russell, 2010), in addition to SOA formed from aged olive tree burning emissions (Kostenidou et al., 2013) and SOA products from smog chamber oxidation of $\alpha$-pinene $(\mathrm{OH})(\mathrm{Chhabra}$ et al., 2011).

$1 \mathrm{a}_{\mathrm{AMS}}$ and OOA-1 $\mathrm{b}_{\mathrm{AMS}}$ make it difficult to justify separating them into different factors.

The small chemical differences in biomass burning and biogenic OM result in several FTIR spectral differences (Fig. 6). FTIR spectra with high biomass burning contributions of OM contain sharp methylene peaks $\left(2920 \mathrm{~cm}^{-1}\right.$ and $2850 \mathrm{~cm}^{-1}$ ), especially for freshly burned vegetative material. The larger contribution of methylene is likely associated with the more vigorous lofting of partially burnt vegetative material associated with wildfire wind conditions. In addition, the biomass burning factor has strong carbonyl group absorbance (Fig. 6), with little associated acid hydroxyl groups except after substantial atmospheric processing. Biogenic aerosol factors and $\alpha$-pinene SOA products contain a broad, often nearly constant, absorbance region of multiple overlapping peaks that extends from $2800 \mathrm{~cm}^{-1}$ to $3300 \mathrm{~cm}^{-1}$, in addition to weak ammonium absorbance and a consistent alcohol group fraction.

These distinctive FTIR spectral characteristics of biomass burning and biogenic OM are remarkably consistent with factors from other campaigns as well as with reference spectra, as shown in Fig. 6. The Hyytiälä $\mathrm{BB}_{\mathrm{FTIR}}$ factor spectra are quite similar to biomass burning factor spectra from Whistler (Canada) and Scripps Pier (La Jolla, CA) (Takahama et al., 2011; Hawkins and Russell, 2010). In addition, we show here as a reference material for biomass burning 
a sample collected during a controlled burn of olive tree branches (Kostenidou et al., 2013). Even though the forest fires in Russia were not olive trees, the olive tree branch burning serves as a suitable reference for comparison to forest (mostly boreal and deciduous) BBOA since most vegetative material contains more than $80 \%$ cellulose. BB $_{\text {FTIR was }}$ found to correlate moderately with olive tree branch burning OM for all wavenumbers $(r=0.6)$. The only substantial difference in the spectra from these burning samples was the carbonyl region and strong correlation was found when the region excluded from the analysis $(r=0.9)$. Compared to other FTIR biogenic SOA factors, the Hyytiälä BIO FTIR factor is very similar to the biogenic factor spectra identified for two different summertime studies at Whistler (Schwartz et al., 2010; Takahama et al., 2011). For comparison to a reference spectrum of biogenic SOA, the spectrum of SOA products from $\mathrm{OH}$ oxidation of $\alpha$-pinene is shown (Chhabra et al., 2011), and the correlation of this FTIR spectrum with Hyytiälä BIO FTIR was very strong $(r=0.97)$.

The spectral similarities between Hyytiälä $\mathrm{BB}_{\mathrm{FTIR}}$ and

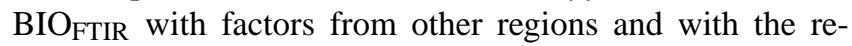
spective reference OM (namely olive tree burning BBOA and $\alpha$-pinene chamber SOA) is striking. Such strong similarities indicate three important points: (1) The similarities in the alkane absorbance region indicate that the carbon backbones of both primary OM and secondary OM precursors are retained by the nondestructive aspect of FTIR spectroscopy. (2) The similarities in the ratios of carboxylic acid and carbonyl groups indicate that the relative amounts of oxidized functional groups produced from each type of precursor are relatively invariant, suggesting that region-specific differences in oxidants (e.g. $\mathrm{OH}, \mathrm{O}_{3}$, and $\mathrm{NO}_{3}$ levels) may have little effect on the OFG composition. (3) Oxidized OFG tend to dominate both biogenic and biomass burning OM. For biogenic OM, this high degree of oxygenation is the result of both oxygenated SOA and small submicron contributions of oxygenated POA from vegetative detritus. For biomass burning, the O-OFG may result largely from oxygenated combustion product POA and small increases in oxygenated OFG with transport time.

One difference in the biomass burning factors is that Scripps Pier and Whistler (2009) had negligible amounts of alcohol group in the biomass burning factors (7\% and $2 \%$, respectively), whereas the Hyytiälä factor had a high alcohol group fraction (25\%). The higher alcohol group contribution at Hyytiälä may be because this campaign had fewer competing alcohol-group-containing sources (i.e. biogenic marine or vegetative detritus) that could have caused misallocation in other factor analysis (Ahlm et al., 2013; Frossard et al., 2011; Hawkins and Russell, 2010; Hawkins et al., 2010; Liu et al., 2012). Even though $B_{\text {FTIR }}$ alcohol group fraction (25\%) was higher than the Scripps Pier and Whistler (2009) ( $2 \%$ and $7 \%$, respectively), the olive tree burning reference $\mathrm{OM}$ has an even higher alcohol group fraction (30\%), indicating that the Hyytiälä fraction is well within the possible range of alcohol group fraction expected for biomass burning sources.

The chemical sensitivity of the FTIR method is partly explained by the nondestructive nature of FTIR spectroscopy, which retains a larger signal from the unbroken carbon backbone of source OM, allowing for easier separation of different types of oxygenated OM. In addition, FTIR provides information about both the degree of oxidation $(\mathrm{O} / \mathrm{C})$ and the type of O-OFG. The advantages of functional group composition over elemental ratios $(\mathrm{O} / \mathrm{C})$ are illustrated by Fig. 7, which shows the functional group equivalent of a Van Krevelen diagram, with the fraction of alkane groups analogous to $\mathrm{H} / \mathrm{C}$ and the sum of the O-OFG group fraction analogous to $\mathrm{O} / \mathrm{C}$, and Fig. $7 \mathrm{~b}$ separates the $\mathrm{O} / \mathrm{C}$ by type of O-OFG (hydroxyl versus carbonyl-containing groups). Biomass burning and biogenic factors cover overlapping ranges in Fig. 7a because their $\mathrm{O} / \mathrm{C}$ and $\mathrm{H} / \mathrm{C}$ are not distinct; however, the two types are clearly separated in Fig. 7b.

Figure $7 \mathrm{a}$ and $\mathrm{b}$ also clearly illustrate that biomass burning factors identified in different regions have varying amounts of oxygenated carbon, likely associated with the transport time. Fresh olive tree burning emissions were less than 1 day old and had the lowest oxygenated group fraction (48\%), followed by biomass burning OM from Monterey measured at Scripps Pier (53\%) which was estimated to be between 2-4 days old (Hawkins and Russell, 2010), and finally Hyytiälä $\mathrm{BB}_{\mathrm{FTIR}}$ with 4-5 day old biomass burning aerosol with the highest O-OFG fraction (73\%). The differences in O-OFG mass fractions and estimated transport times of BBOA are also evident in the varying molar ratios of carbonyl (nonacidic) group to alkane group (0.01-0.38), with lowest corresponding to the reference of olive tree burning $\mathrm{OM}$ and highest to the highly oxygenated Hyytiälä BB $\mathrm{BB}_{\text {FTIR }}$ factor. These differences were not evident in the nearly constant molar ratios of carboxylic acid group to alkane group (0.04-0.05) (Fig. 8b). Increasing molar ratios of carbonyl group to alkane group could indicate $\mathrm{OH}$ oxidation of longchain alkanes that form alkyl peroxides in first-generation monofunctional products (Russell et al., 2011). An additional source of carbonyls in carbonaceous particles includes $\mathrm{OH}$ oxidation of aromatics (Lee and Lane, 2009, 2010; Wang et al., 2007; Webb et al., 2006), a common precursor found in biomass plumes (Reid et al., 2005). The other difference between the O-OFG for the biomass burning reference (i.e. olive tree branches) and the other factors is that the olive tree burning reference $\mathrm{OM}$ has the highest alcohol group fraction $(30 \%)$ and the lowest carbonyl and carboxylic acid group $\left(\mathrm{COR}{ }^{\prime}+\mathrm{COOH}\right)$ fraction $(18 \%)$.

The differences in the factor and reference spectra for biogenic $\mathrm{OM}$ were smaller, with alkane group fraction varying from $25 \%$ to $40 \%$ and O-OFG varying from $53 \%$ to $64 \%$ (Fig. 8a). The same is true when looking at the fraction of alcohol (12-23\%) and (COR' $+\mathrm{COOH})(35-52 \%)$ groups. The consistency of molar ratios of carbonyl group to alkane group (0.08-0.13) and of carboxylic acid group to alkane 

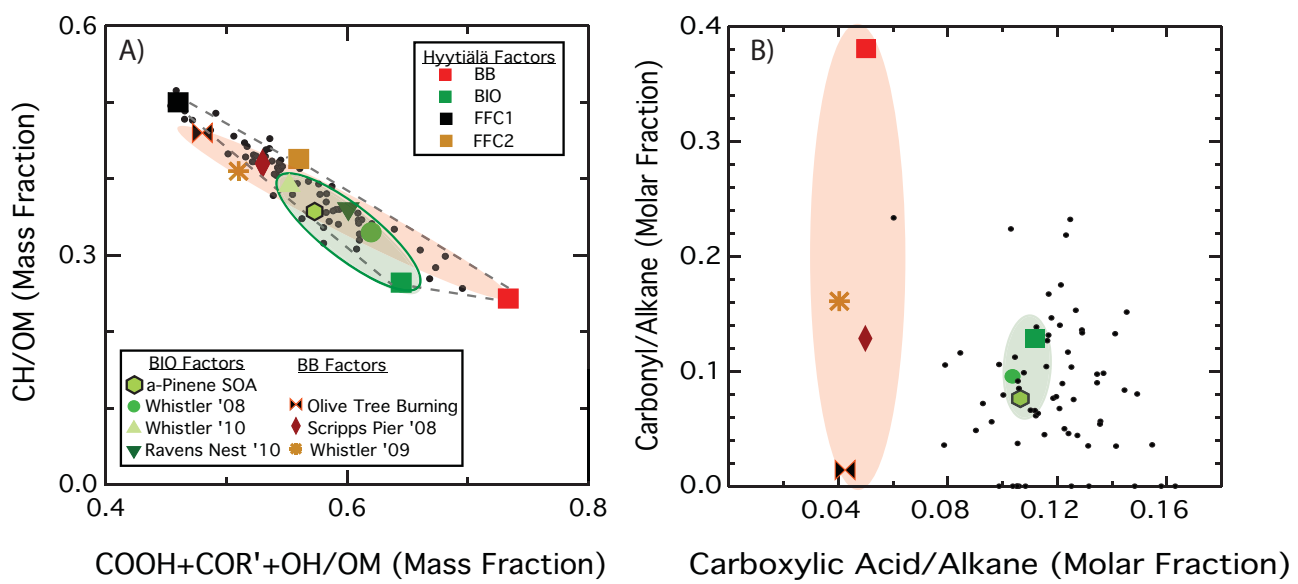

Fig. 7. (A) Distribution of oxygenated functional groups in ambient aerosol (black circles) and PMF factors in terms of mass fractions for biogenic and biomass burning factors: Hyytiälä, Whistler 2008 (Schwartz et al., 2010), Whistler 2009 (Takahama et al., 2011), Whistler 2010 (including Raven's Nest) (Ahlm et al., 2012), Scripps Pier 2008 (Hawkins and Russell, 2010), POA formed from aged olive tree burning emissions (Kostenidou et al., 2013) and SOA from $\alpha$-pinene oxidation (Chhabra et al., 2011). (B) Molar fractions of carbonyl (nonacid carbonyl) and carboxylic acid. Markers correspond to those presented in legend found in (A). Red and green shaded regions correspond to typical distributions of biomass burning and biogenic factors, respectively.

group (0.10-0.11) for both biogenic factors and $\alpha$-pinene SOA is also shown in Fig. 8b.

During July and August 2010, OM at Hyytiälä was $4.4 \mu \mathrm{g} \mathrm{m}^{-3}$ on average with a maximum concentration of $21 \mu \mathrm{g} \mathrm{m}^{-3}$, higher than $\mathrm{OM}$ measured in previous springtime (1.20 to $1.24 \mu \mathrm{g} \mathrm{m}^{-3}$; Finessi et al., 2012; Raatikainen et al., 2010) or summertime (1.7-2.2 $\mu \mathrm{g} \mathrm{OC} \mathrm{m}^{-3}$; Kourtchev et al., 2009; Yttri et al., 2011) campaigns. Consistent with our results, these studies have found that biogenic OM makes up approximately one-third of submicron OM in Hyytiälä. During HUMPPA-COPEC, the majority of the remaining OM was from transported emissions (i.e. biomass burning and fossil fuel combustion), making rural Hyytiälä not as pristine or remote in character as one might think. This meant that even though the biogenic OA was higher than previously reported at $1.7 \mu \mathrm{g} \mathrm{m}^{-3}$, its fraction of OM was only $35 \%$ based on PMF from both AMS and FTIR. While this apportionment is subject to the uncertainties inherent to statistical inversions, the PMF-based separation of biomass burning and biogenic OM at Hyytiälä, Finland, has the advantage of two time series of detailed organic composition measurements that included multiple periods when either biogenic or biomass burning OM substantially outweighed the other (Fig. 3).

\section{Conclusions}

The organic fraction of submicron particle mass at Hyytiälä has substantial biogenic and biomass burning components ( $35 \%$ and $25 \%$, respectively), perhaps particularly so in the warm and dry months of summer. While this apportionment is subject to the uncertainties of statistical data inversions, the overall consistency between FTIR, AMS, and tracer measurements provides evidence for its robustness. The biogenic components include contributions from the large areas of boreal forests that characterize the region surrounding the sampling site. The biomass burning contribution of OM was the result of aged biomass burning plumes that had been transported for hundreds of miles (with an average transport time of 4-5 days). The robustness of this apportionment is supported by the agreement of two independent analytical methods for organic measurements with three statistical techniques.

The OM during the project included $1.7 \mu \mathrm{g} \mathrm{m}^{-3}$ submicron $\mathrm{OM}$ from biogenic emissions and $1.2 \mu \mathrm{g} \mathrm{m}^{-3}$ from transported biomass burning aerosol emissions. Compared to previous studies at Hyytiälä, the summertime biogenic $\mathrm{OM}$ is 1.5 to 3 times larger than springtime biogenic $\mathrm{OM}$ $\left(0.64 \mu \mathrm{g} \mathrm{m}^{-3}\right.$ and $0.4 \mu \mathrm{g} \mathrm{m}^{-3}$, measured in 2005 and 2007, respectively), although it still contributed only $35 \%$ of OM. Such differences in summertime and springtime biogenic OM can be attributed to summertime BVOC emissions, which are increased by $200-400 \%$ over annual averages (Hakola et al., 2009). The high biogenic OM during HUMPPA-COPEC was not surprising, since these temperature-driven increases in BVOC emissions have been shown to result in substantially enhanced concentrations of biogenic OM (Leaitch et al., 2011).

In addition to the biogenic and biomass burning sources, the remaining $39 \%$ of OM was largely associated with fossil fuel emissions from motor vehicles or other fossil fuel combustion sources. A unique intermittent local source of biogenic-like emissions was a nearby sawmill operation (Korkeakoski, Finland, located $10 \mathrm{~km}$ SE of Hyytiälä), which 
contributed $60 \%$ of OM when the wind was from the southeast during nighttime hours (midnight-4 a.m.). The short dark periods of high-latitude summer nights meant that photochemical reactions could continue throughout much of the night.

Distinguishing the chemical differences between biomass burning and biogenic sources is challenging, since both the primary and secondary contributions originate from terrestrial vegetation. As a consequence, primary components of both sources include cellulose-breakdown products, and secondary components include oxidation products of monoterpenes and other terpenoid compounds. These inherent chemical similarities were more clearly identified in the FTIR spectra than in the mass fragment spectra, with the differences evident in (1) the higher nonacidic carbonyl groups present in the biomass burning organic factor, possibly a characteristic of their further oxidation by higher temperatures in plume conditions and (2) the presence of methylene peaks characteristic of longer-hydrocarbon-chain waxes that are lofted in greater amounts in windy conditions commonly associated with wildfires. Mass fragments in the OOA- $1 \mathrm{~b}_{\mathrm{AMS}}$ factor spectra did not include characteristic BB fragments reported by other studies and greatly resembled those found in OOA-1aAMS, likely due to atmospheric processing of the biomass burning plume which was transported for 4-5 days prior to arriving at Hyytiälä. However, AMS factor analysis could separate sources by temporal correlation with particle- and gas-phase tracers, even though there were only negligible differences in mass fragments within the factor spectra. In past studies that lacked such tracers, biogenic and oxidized biomass burning organic aerosol may have been considered to be inseparable, since its chemical characteristics were not evident in mass-fragment-based $\mathrm{O} / \mathrm{C}$ retrievals. This study demonstrates that SOA transported multiple days from different sources may have indistinguishable AMS mass fragment spectra but different FTIR spectra, showing that functional group absorption provides more information than mass fragment spectra $\left(\right.$ at $600^{\circ} \mathrm{C}$ ) for distinguishing types of highly oxidized SOA.

\section{Supplementary material related to this article is available online at http://www.atmos-chem-phys.net/13/ 12233/2013/acp-13-12233-2013-supplement.pdf.}

Acknowledgements. The authors acknowledge NSF grant ATM0904203 for funding. A. L. Corrigan gratefully acknowledges support by the Department of Energy Office of Science Graduate Fellowship Program (DOE SCGF), made possible in part by the American Recovery and Reinvestment Act of 2009 (DE-AC0506OR23100). HUMPPA-COPEC measurements and analyses were supported by the ERC grant ATMNUCLE (project no. 227463), Academy of Finland Centre of Excellence program (project no. 1118615), the European Integrated project on Aerosol Cloud Climate and Air Quality Interactions EUCAARI (project no. 036833-2), the EUSAAR TNA (project no. 400586), and the IMECC TA (project no. 4006261). We thank the Hyytiälä engineers and staff for support during the campaign, Pasi Aalto for his support with filter equipment and Spyros Pandis for providing biomass burning aerosol samples.

Edited by: A. Goldstein

\section{References}

Aalto, P., Hämeri, K., Becker, E., Weber, R., Mäkelä, J., Hoell, C., O’Dowd, C., Karlsson, H., Hansson, H., Väkevä, M., Koponen, I., Buzorius, G., and Kulmala, M.: Physical characterization of aerosol particles during nucleation events, Tellus B, 36, 344-358, doi:10.1034/j.1600-0889.2001.530403.x, 2001.

Ahlm, L., Shakya, K. M., Russell, L. M., Schroder, J. C., Wong, J. P. S., Sjostedt, S. J., Hayden, K. L., Liggio, J., Wentzell, J. J. B., Wiebe, H. A., Mihele, C., Leaitch, W. R., and Macdonald, A. M.: Temperature-dependent accumulation mode particle and cloud nuclei concentrations from biogenic sources during WACS 2010, Atmos. Chem. Phys., 13, 3393-3407, doi:10.5194/acp-133393-2013, 2013.

Aiken, A. C., Decarlo, P. F., Kroll, J. H., Worsnop, D. R., Huffman, J. A., Docherty, K. S., Ulbrich, I. M., Mohr, C., Kimmel, J. R., Sueper, D., Sun, Y., Zhang, Q., Trimborn, A., Northway, M., Ziemann, P. J., Canagaratna, M. R., Onasch, T. B., Alfarra, M. R., Prevot, A. S. H., Dommen, J., Duplissy, J., Metzger, A., Baltensperger, U., and Jimenez, J. L.: O/C and OM/OC ratios of primary, secondary, and ambient organic aerosols with highresolution time-of-flight aerosol mass spectrometry, Environ. Sci. Technol., 42, 4478-4485, doi:10.1021/es703009q, 2008.

Alfarra, M. R., Coe, H., Allan, J. D., Bower, K. N., Boudries, H., Canagaratna, M. R., Jimenez, J. L., Jayne, J. T., Garforth, A. A., Li, S. M., and Worsnop, D. R.: Characterization of urban and rural organic particulate in the lower fraser valley using two aerodyne aerosol mass spectrometers, Atmos. Environ., 38, 57455758, doi:10.1016/j.atmosenv.2004.01.054, 2004.

Allan, J., Jimenez, J. L., Williams, P., Alfarra, M., Bower, K., jayne, J. T., Coe, H., and Worsnop, D. R.: Quantitative sampling using an aerodyne aerosol mass spectrometer: 1 . Techniques of data interpretation and error analysis, J. Geophys. Res.-Atmos., 108, 4090, doi:10.1029/2002JD002358, 2003.

Andreae, M. O.: Soot carbon and excess fine potassium - longrange transport of combustion-derived aerosols, Science, 220, 1148-1151, doi:10.1126/science.220.4602.1148, 1983.

Andreae, M. O., Fishman, J., and Lindesay, J.: The southern tropical atlantic region experiment (stare): Transport and atmospheric chemistry near the equator-atlantic (trace a) and southern african fire-atmosphere research initiative (safari): An introduction, J. Geophys. Res.-Atmos., 101, 23519-23520, 1996.

Atkinson, R.: Atmospheric chemistry of VOCs and $\mathrm{NO}_{\mathrm{x}}$, Atmos. Environ., 34, 2063-2101, doi:10.1016/s1352-2310(99)00460-4, 2000.

Bäck, J., Aalto, J., Kolari, P., Hari, P., and Kulmala, M.: Contribution of developing foliage to canopy emissions of volatile organic compounds, Atmos. Chem. Phys. Discuss., in preparation, 2013.

Bianchi, G., Gamba, A., Limiroli, R., Pozzi, N., Elster, R., Salamini, F., and Bartels, D.: The unusual sugar composition in leaves of 
the resurrection plant myrothamnus-flabellifolia, Physiol. Plant., 87, 223-226, doi:10.1034/j.1399-3054.1993.870215.x, 1993.

Bond, T. C., Streets, D. G., Yarber, K. F., Nelson, S. M., Woo, J. H., and Klimont, Z.: A technology-based global inventory of black and organic carbon emissions from combustion, J. Geophys. Res.-Atmos., 109, D14203, doi:10.1029/2003JD003697, 2004.

Budisulistiorini, S. H., Canagaratna, M. R., Croteau, P. L., Marth, W. J., Baumann, K., Edgerton, E. S., Shaw, S. L., Knipping, E. M., Worsnop, D., Jayne, J. T., Gold, A., and Surratt, J.: Realtime continuous characterization of secondary organic aerosol derived from isoprene epoxydiols in downtown atlanta, georgia using the aerodyne aerosol chemical speciation monitor, Environ. Sci. Technol., 47, 5686-5694, 2013.

Canagaratna, M. R., Jayne, J. T., Jimenez, J. L., Allan, J. D., Alfarra, M. R., Zhang, Q., Onasch, T. B., Drewnick, F., Coe, H., Middlebrook, A., Delia, A., Williams, L. R., Trimborn, A. M., Northway, M. J., DeCarlo, P. F., Kolb, C. E., Davidovits, P., and Worsnop, D. R.: Chemical and microphysical characterization of ambient aerosols with the aerodyne aerosol mass spectrometer, Mass Spectrom. Rev., 26, 185-222, doi:10.1002/mas.20115, 2007.

Carlton, A. G., Pinder, R. W., Bhave, P. V., and Pouliot, G. A.: To what extent can biogenic soa be controlled?, Environ. Sci. Technol., 44, 3376-3380, doi:10.1021/es903506b, 2010.

Cass, G. R.: Organic molecular tracers for particulate air pollution sources, Trac-Trends Anal. Chem., 17, 356-366, doi:10.1016/s0165-9936(98)00040-5, 1998.

Chen, Q., Farmer, D. K., Schneider, J., Zorn, S. R., Heald, C. L., Karl, T. G., Guenther, A., Allan, J. D., Robinson, N., Coe, H., Kimmel, J. R., Pauliquevis, T., Borrmann, S., Poschl, U., Andreae, M. O., Artaxo, P., Jimenez, J. L., and Martin, S. T.: Mass spectral characterization of submicron biogenic organic particles in the amazon basin, Geophys. Res. Lett., 36, L20806, doi:10.1029/2009g1039880, 2009.

Chhabra, P. S., Ng, N. L., Canagaratna, M. R., Corrigan, A. L., Russell, L. M., Worsnop, D. R., Flagan, R. C., and Seinfeld, J. H.: Elemental composition and oxidation of chamber organic aerosol, Atmos. Chem. Phys., 11, 8827-8845, doi:10.5194/acp-11-88272011, 2011.

Crutzen, P. J. and Andreae, M. O.: Biomass burning in the tropics - impact on atmospheric chemistry and biogeochemical cycles, Science, 250, 1669-1678, doi:10.1126/science.250.4988.1669, 1990.

Cubison, M. J., Ortega, A. M., Hayes, P. L., Farmer, D. K., Day, D., Lechner, M. J., Brune, W. H., Apel, E., Diskin, G. S., Fisher, J. A., Fuelberg, H. E., Hecobian, A., Knapp, D. J., Mikoviny, T., Riemer, D., Sachse, G. W., Sessions, W., Weber, R. J., Weinheimer, A. J., Wisthaler, A., and Jimenez, J. L.: Effects of aging on organic aerosol from open biomass burning smoke in aircraft and laboratory studies, Atmos. Chem. Phys., 11, 12049-12064, doi:10.5194/acp-11-12049-2011, 2011.

Day, D. A., Liu, S., Russell, L. M., and Ziemann, P. J.: Organonitrate group concentrations in submicron particles with high nitrate and organic fractions in coastal southern california, Atmos. Environ., 44, 1970-1979, doi:10.1016/j.atmosenv.2010.02.045, 2010.

DeCarlo, P. F., Dunlea, E. J., Kimmel, J. R., Aiken, A. C., Sueper, D., Crounse, J., Wennberg, P. O., Emmons, L., Shinozuka, Y., Clarke, A., Zhou, J., Tomlinson, J., Collins, D. R., Knapp, D.,
Weinheimer, A. J., Montzka, D. D., Campos, T., and Jimenez, J. L.: Fast airborne aerosol size and chemistry measurements above Mexico City and Central Mexico during the MILAGRO campaign, Atmos. Chem. Phys., 8, 4027-4048, doi:10.5194/acp-84027-2008, 2008.

DeCarlo, P. F., Ulbrich, I. M., Crounse, J., de Foy, B., Dunlea, E. J., Aiken, A. C., Knapp, D., Weinheimer, A. J., Campos, T., Wennberg, P. O., and Jimenez, J. L.: Investigation of the sources and processing of organic aerosol over the central mexican plateau from aircraft measurements during milagro, Atmos. Chem. Phys., 10, 5257-5280, doi:10.5194/acp-10-5257-2010, 2010.

Draxler, R. R. and Rolph, G. D.: HYSPLIT (HYbrid Single-Particle Lagrangian Integrated Trajectory) Model access via NOAA ARL READY Website, edited by R. R. Draxler and G. D. Rolph, NOAA Air Resour. Lab., Silver Springs, MD, http://ready.arl. noaa.gov/HYSPLIT.php, 2013.

HYSPLIT (Hybrid Single-Particle Lagrangian Integrated Trajectory) model access via NOAA ARL ready website: http://ready. arl.noaa.gov/HYSPLIT.php, 2013.

Drewnick, F., Hings, S. S., DeCarlo, P., Jayne, J. T., Gonin, M., Fuhrer, K., Weimer, S., Jimenez, J. L., Demerjian, K. L., Borrmann, S., and Worsnop, D. R.: A new time-of-flight aerosol mass spectrometer (tof-ams) - instrument description and first field deployment, Aerosol Sci. Technol., 39, 637-658, doi:10.1080/02786820500182040, 2005.

Eerdekens, G., Yassaa, N., Sinha, V., Aalto, P. P., Aufmhoff, H., Arnold, F., Fiedler, V., Kulmala, M., and Williams, J.: Voc measurements within a boreal forest during spring 2005: On the occurrence of elevated monoterpene concentrations during night time intense particle concentration events, Atmos. Chem. Phys., 9, 8331-8350, doi:10.5194/acp-9-8331-2009, 2009.

Engling, G., Carrico, C. M., Kreldenweis, S. M., Collett, J. L., Jr., Day, D. E., Malm, W. C., Lincoln, E., Hao, W. M., Iinuma, Y., and Herrmann, H.: Determination of levoglucosan in biomass combustion aerosol by high-performance anion-exchange chromatography with pulsed amperometric detection, Atmos. Environ., 40, S299-S311, doi:10.1016/j.atmosenv.2005.12.069, 2006.

Finessi, E., Decesari, S., Paglione, M., Giulianelli, L., Carbone, C., Gilardoni, S., Fuzzi, S., Saarikoski, S., Raatikainen, T., Hillamo, R., Allan, J., Mentel, T. F., Tiitta, P., Laaksonen, A., Petaja, T., Kulmala, M., Worsnop, D. R., and Facchini, M. C.: Determination of the biogenic secondary organic aerosol fraction in the boreal forest by nmr spectroscopy, Atmos. Chem. Phys., 12, 941959, doi:10.5194/acp-12-941-2012, 2012.

Frossard, A. A., Shaw, P. M., Russell, L., Kroll, J. H., Canagaratna, M. R., Worsnop, D. R., Quinn, P. K., and Bates, T. S.: Springtime arctic haze contributions of submicron organic particles from european and asian combustion sources, J. Geophys. Res., 116, D05205, doi:10.1029/2010JD015178, 2011.

Fu, P. Q., Kawamura, K., Kanaya, Y., and Wang, Z. F.: Contributions of biogenic volatile organic compounds to the formation of secondary organic aerosols over mt tai, central east china, Atmos. Environ., 44, 4817-4826, doi:10.1016/j.atmosenv.2010.08.040, 2010.

Geller, M. D., Biswas, S., Fine, P. A., and Sioutas, C.: A new compact aerosol concentrator for use in conjunction with low flow- 
rate continuous aerosol instrumentation, Journal of Aerosol Science, 36, 1006-1022, doi:10.1016/j.jaerosci.2004.11.015, 2005.

Gilardoni, S., Russell, L. M., Sorooshian, A., Flagan, R. C., Seinfeld, J. H., Bates, T. S., Quinn, P. K., Allan, J. D., Williams, B., Goldstein, A. H., Onasch, T. B., and Worsnop, D. R.: Regional variation of organic functional groups in aerosol particles on four us east coast platforms during the international consortium for atmospheric research on transport and transformation 2004 campaign, J. Geophys. Res.-Atmos., 112, D10S27, doi:10.1029/2006jd007737, 2007.

Gómez-González, Y., Wang, W., Vermeylen, R., Chi, X., Neirynck, J., Janssens, I. A., Maenhaut, W., and Claeys, M.: Chemical characterisation of atmospheric aerosols during a 2007 summer field campaign at Brasschaat, Belgium: sources and source processes of biogenic secondary organic aerosol, Atmos. Chem. Phys., 12, 125-138, doi:10.5194/acp-12-125-2012, 2012.

Greenberg, J. P., Friedli, H., Guenther, A. B., Hanson, D., Harley, P., and Karl, T.: Volatile organic emissions from the distillation and pyrolysis of vegetation, Atmos. Chem. Phys., 6, 81-91, doi:10.5194/acp-6-81-2006, 2006.

Grieshop, A. P., Logue, J. M., Donahue, N. M., and Robinson, A. L.: Laboratory investigation of photochemical oxidation of organic aerosol from wood fires 1: measurement and simulation of organic aerosol evolution, Atmos. Chem. Phys., 9, 1263-1277, doi:10.5194/acp-9-1263-2009, 2009.

Grönroos, J., Mattila, P., Regina, K., Nousiainen, J., Perala, P., Saarinen, K., and Mikkola-Pusa, J.: Development of the ammonia emission inventory in finland, Finnish Environment Institute, Helsinki, 2009.

Guenther, A., Hewitt, C. N., Erickson, D., Fall, R., Geron, C., Graedel, T., Harley, P., Klinger, L., Lerdau, M., McKay, W. A., Pierce, T., Scholes, B., Steinbrecher, R., Tallamraju, R., Taylor, J., and Zimmerman, P.: A global-model of natural volatile organic-compound emissions, J. Geophys. Res.-Atmos., 100, 8873-8892, doi:10.1029/94JD02950, 1995.

Guenther, A. B., Zimmerman, P. R., Harley, P. C., Monson, R. K., and Fall, R.: Isoprene and monoterpene emission rate variability - model evaluations and sensitivity analyses, J. Geophys. Res.Atmos., 98, 12609-12617, doi:10.1029/93JD00527, 1993.

Hakola, H., Hellen, H., Tarvainen, V., Back, J., Patokoski, J., and Rinne, J.: Annual variations of atmospheric voc concentrations in a boreal forest, Bor. Environ. Res., 14, 722-730, 2009.

Hallquist, M., Wenger, J. C., Baltensperger, U., Rudich, Y., Simpson, D., Claeys, M., Dommen, J., Donahue, N. M., George, C., Goldstein, A. H., Hamilton, J. F., Herrmann, H., Hoffmann, T., Iinuma, Y., Jang, M., Jenkin, M. E., Jimenez, J. L., Kiendler-Scharr, A., Maenhaut, W., McFiggans, G., Mentel, Th. F., Monod, A., Prévôt, A. S. H., Seinfeld, J. H., Surratt, J. D., Szmigielski, R., and Wildt, J.: The formation, properties and impact of secondary organic aerosol: current and emerging issues, Atmos. Chem. Phys., 9, 5155-5236, doi:10.5194/acp-9-51552009, 2009.

Hari, P. and Kulmala, M.: Station for measuring ecosystematmosphere relations (smear ii), Bor. Environ. Res., 10, 315-322, 2005.

Hawkins, L. N. and Russell, L. M.: Oxidation of ketone groups in transported biomass burning aerosol from the 2008 northern california lightning series fires, Atmos. Environ., 44, 4142-4154, doi:10.1016/j.atmosenv.2010.07.036, 2010.
Hawkins, L. N., Russell, L. M., Covert, D. S., Quinn, P. K., and Bates, T. S.: Carboxylic acids, sulfates, and organosulfates in processed continental organic aerosol over the southeast pacific ocean during vocals-rex 2008, J. Geophys. Res.-Atmos., 115, D13201, doi:10.1029/2009jd013276, 2010.

Hennigan, C. J., Sullivan, A. P., Collett Jr., J. L., and Robinson, A. L.: Levoglucosan stability in biomass burning particles exposed to hydroxyl radicals, Geophys. Res. Lett., 37, L09806, doi:10.1029/2010GL043088, 2010.

Hennigan, C. J., Miracolo, M. A., Engelhart, G. J., May, A. A., Presto, A. A., Lee, T., Sullivan, A. P., McMeeking, G. R., Coe, H., Wold, C. E., Hao, W. M., Gilman, J. B., Kuster, W. C., de Gouw, J., Schichtel, B. A., Collett, J. L., Jr., Kreidenweis, S M., and Robinson, A. L.: Chemical and physical transformations of organic aerosol from the photo-oxidation of open biomass burning emissions in an environmental chamber, Atmos. Chem. Phys., 11, 7669-7686, doi:10.5194/acp-11-7669-2011, 2011.

Heringa, M. F., DeCarlo, P. F., Chirico, R., Tritscher, T., Dommen, J., Weingartner, E., Richter, R., Wehrle, G., Prevot, A. S. H., and Baltensperger, U.: Investigations of primary and secondary particulate matter of different wood combustion appliances with a high-resolution time-of-flight aerosol mass spectrometer, Atmos. Chem. Phys., 11, 5945-5957, doi:10.5194/acp-11-59452011, 2011.

Hildebrandt, L., Engelhart, G. J., Mohr, C., Kostenidou, E., Lanz, V. A., Bougiatioti, A., DeCarlo, P. F., Prevot, A. S. H., Baltensperger, U., Mihalopoulos, N., Donahue, N. M., and Pandis, S. N.: Aged organic aerosol in the eastern mediterranean: The finokalia aerosol measurement experiment-2008, Atmos. Chem. Phys., 10, 4167-4186, doi:10.5194/acp-10-4167-2010, 2010.

Hoffmann, D., Tilgner, A., Iinuma, Y., and Herrmann, H.: Atmospheric stability of levoglucosan: A detailed laboratory and modeling study, Environ. Sci. Technol., 44, 694-699, doi:10.1021/es902476f, 2010.

Hole, L. R., Christensen, J. H., Ruoho-Airola, T., Torseth, K., Ginzburg, V., and Glowacki, P.: Past and future trends in concentrations of sulphur and nitrogen compounds in the arctic, Atmos. Environ., 43, 928-939, 2009.

Holzinger, R., Warneke, C., Hansel, A., Jordan, A., Lindinger, W., Scharffe, D. H., Schade, G., and Crutzen, P. J.: Biomass burning as a source of formaldehyde, acetaldehyde, methanol, acetone, acetonitrile, and hydrogen cyanide, Geophys. Res. Lett., 26, 1161-1164, doi:10.1029/1999g1900156, 1999.

Hoyle, C. R., Boy, M., Donahue, N. M., Fry, J. L., Glasius, M., Guenther, A., Hallar, A. G., Hartz, K. H., Petters, M. D., Petaja, T., Rosenoern, T., and Sullivan, A. P.: A review of the anthropogenic influence on biogenic secondary organic aerosol, Atmos. Chem. Phys., 11, 321-343, doi:10.5194/acp-11-321-2011, 2011.

Jimenez, J. L., Canagaratna, M. R., Donahue, N. M., Prevot, A. S. H., Zhang, Q., Kroll, J. H., DeCarlo, P. F., Allan, J. D., Coe, H., Ng, N. L., Aiken, A. C., Docherty, K. S., Ulbrich, I. M., Grieshop, A. P., Robinson, A. L., Duplissy, J., Smith, J. D., Wilson, K. R., Lanz, V. A., Hueglin, C., Sun, Y. L., Tian, J., Laaksonen, A., Raatikainen, T., Rautiainen, J., Vaattovaara, P., Ehn, M., Kulmala, M., Tomlinson, J. M., Collins, D. R., Cubison, M. J., Dunlea, E. J., Huffman, J. A., Onasch, T. B., Alfarra, M. R., Williams, P. I., Bower, K., Kondo, Y., Schneider, J., Drewnick, F., Borrmann, S., Weimer, S., Demerjian, K., Salcedo, D., Cottrell, L., Griffin, R., Takami, A., Miyoshi, T., 
Hatakeyama, S., Shimono, A., Sun, J. Y., Zhang, Y. M., Dzepina, K., Kimmel, J. R., Sueper, D., Jayne, J. T., Herndon, S. C., Trimborn, A. M., Williams, L. R., Wood, E. C., Middlebrook, A. M., Kolb, C. E., Baltensperger, U., and Worsnop, D. R.: Evolution of organic aerosols in the atmosphere, Science, 326, 1525-1529, doi:10.1126/science.1180353, 2009.

Johnson, A.: The development and deployment of fotos: A fast observation of trace organics system, PhD, Department of Atmospheric Chemistry, Max Planck Institute for Chemistry, Mainz, 2011.

Junninen, H., Lauri, A., Keronen, P., Aalto, P., Hiltunen, V., Hari, P., and Kulmala, M.: Smart-smear: On-line data exploration and visualization tool for smear stations, Bor. Environ. Res., 14, 447457, 2009.

Kessler, S. H., Smith, J. D., Che, D. L., Worsnop, D. R., Wilson, K. R., and Kroll, J. H.: Chemical sinks of organic aerosol: Kinetics and products of the heterogeneous oxidation of erythritol and levoglucosan, Environ. Sci. Technol., 44, 7005-7010, doi:10.1021/es101465m, 2010.

Kiendler-Scharr, A., Zhang, Q., Hohaus, T., Kleist, E., Mensah, A., Mentel, T. F., Spindler, C., Uerlings, R., Tillmann, R., and Wildt, J.: Aerosol mass spectrometric features of biogenic soa: Observations from a plant chamber and in rural atmospheric environments, Environ. Sci. Technol., 43, 8166-8172, doi:10.1021/es901420b, 2009.

Kostenidou, E., Kaltsonoudis, C., Tsiflikiotou, M., Louvaris, E., Russell, L. M., and Pandis, S. N.: Burning of olive tree branches: a major organic aerosol source in the Mediterranean, Atmos. Chem. Phys., 13, 8797-8811, doi:10.5194/acp-13-8797-2013, 2013.

Kourtchev, I., Copolovici, L., Claeys, M., and Maenhaut, W.: Characterization of atmospheric aerosols at a forested site in central europe, Environ. Sci. Technol., 43, 4665-4671, doi:10.1021/es803055w, 2009.

Kuckelmann, U., Warscheid, S., and Hoffmann, T.: On-line characterization of organic aerosols formed from biogenic precursors using atmospheric pressure chemical ionization mass spectrometry, Anal. Chem., 72, 1905-1912, doi:10.1021/ac991178a, 2000.

Laaksonen, A., Kulmala, M., O’Dowd, C. D., Joutsensaari, J., Vaattovaara, P., Mikkonen, S., Lehtinen, K. E. J., Sogacheva, L., Dal Maso, M., Aalto, P., Petaja, T., Sogachev, A., Yoon, Y. J., Lihavainen, H., Nilsson, D., Facchini, M. C., Cavalli, F., Fuzzi, S., Hoffmann, T., Arnold, F., Hanke, M., Sellegri, K., Umann, B., Junkermann, W., Coe, H., Allan, J. D., Alfarra, M. R., Worsnop, D. R., Riekkola, M. L., Hyotylainen, T., and Viisanen, Y.: The role of voc oxidation products in continental new particle formation, Atmos. Chem. Phys., 8, 2657-2665, doi:10.5194/acp-82657-2008, 2008.

Lanz, V. A., Alfarra, M. R., Baltensperger, U., Buchmann, B., Hueglin, C., and Prevot, A. S. H.: Source apportionment of submicron organic aerosols at an urban site by factor analytical modelling of aerosol mass spectra, Atmos. Chem. Phys., 7, 15031522, doi:10.5194/acp-7-1503-2007, 2007.

Leaitch, W. R., Macdonald, A. M., Brickell, P. C., Liggio, J., Sjosted, S., Vlasenko, A., Bottenheim, J. W., Huang, L., Li, S. M., Liu, P. S. K., Toom-Sauntry, D., Hayden, K. L., Sharma, S., Shantz, N. C., Wiebe, H., Zhang, W., Abbatt, J., Slowik, J., Chang, R. Y. W., Russell, L. M., Schwartz, R. E., Takahama, S., Jayne, J. T., and Ng, N. L.: Temperature response of the submi- cron organic aerosol from temperate forests Atmos. Environ., 45, 6696-6704, doi:10.1016/j.atmosenv.2011.08.047, 2011.

Lee, A., Goldstein, A. H., Kroll, J. H., Ng, N. L., Varutbangkul, V., Flagan, R. C., and Seinfeld, J. H.: Gas-phase products and secondary aerosol yields from the photooxidation of 16 different terpenes, J. Geophys. Res.-Atmos., 111, D17305, doi:10.1029/2006jd007050, 2006.

Lee, J. and Lane, D. A.: Unique products from the reaction of naphthalene with the hydroxyl radical, Atmos. Environ., 43, 48864893, doi:10.1016/j.atmosenv.2009.07.018, 2009.

Lee, J. and Lane, D. A.: Formation of oxidized products from the reaction of gaseous phenanthrene with the oh radical in a reaction chamber, Atmos. Environ., 44, 2469-2477, doi:10.1016/j.atmosenv.2010.03.008, 2010.

Lee, T., Sullivan, A. P., Mack, L., Jimenez, J. L., Kreidenweis, S. M., Onasch, T. B., Worsnop, D. R., Malm, W., Wold, C. E., Hao, W. M., and Collett, J. L.: Chemical smoke marker emissions during flaming and smoldering phases of laboratory open burning of wildland fuels, Aerosol Sci. Technol., 44, I-V, doi:10.1080/02786826.2010.499884, 2010.

Lewis, C. W., Klouda, G. A., and Ellenson, W. D.: Radiocarbon measurement of the biogenic contribution to summertime pm2.5 ambient aerosol in nashville, tn, Atmos. Environ., 38, 60536061, doi:10.1016/j.atmosenv.2004.06.011, 2004.

Liao, L., Dal Maso, M., Taipale, R., Rinne, J., Ehn, M., Junninen, H., Aijala, M., Nieminen, T., Alekseychik, P., Hulkkonen, M., Worsnop, D. R., Kerminen, V. M., and Kulmala, M.: Monoterpene pollution episodes in a forest environment: Indication of anthropogenic origin and association with aerosol particles, Bor. Environ. Res., 16, 288-303, 2011.

Lin, Y. H., Zhang, Z. F., Docherty, K. S., Zhang, H. F., Budisulistiorini, S. H., Rubitschun, C. L., Shaw, S. L., Knipping, E. M., Edgerton, E. S., Kleindienst, T. E., Gold, A., and Surratt, J. D.: Isoprene epoxydiols as precursors to secondary organic aerosol formation: Acid-catalyzed reactive uptake studies with authentic compounds, Environ. Sci. Technol., 46, 250-258, doi:10.1021/es202554c, 2012.

Lindinger, W., Hansel, A., and Jordan, A.: Proton-transfer-reaction mass spectrometry (ptr-ms): On-line monitoring of volatile organic compounds at pptv levels, Chemical Society Reviews, 27, 347-354, doi:10.1039/a827347z, 1998.

Liu, S., Ahlm, L., Day, D., Russell, L., Zhao, Y., Gentner, D., Weber, R., Goldstein, A., Jaoui, M., Offenberg, J., Kleindienst, T., Rubitschun, C., Surratt, J., Sheesley, R., and Scheller, S.: Secondary organic aerosol formation from fossil fuel sources contribute majority of summertime organic mass at bakersfield, J. Geophys Res., 117, D00V26, doi:10.1029/2012JD018170, 2012.

Lobert, J. M., Scharffe, D. H., Hao, W. M., and Crutzen, P. J.: Importance of biomass burning in the atmospheric budgets of nitrogencontaining gases, Nature, 346, doi:10.1038/346552a0, 1990.

Maria, S. F., Russell, L. M., Turpin, B. J., and Porcja, R. J.: Ftir measurements of functional groups and organic mass in aerosol samples over the caribbean, Atmos. Environ., 36, 5185-5196, 2002.

Maria, S. F., Russell, L. M., Turpin, B. J., Porcja, R. J., Campos, T. L., Weber, R. J., and Huebert, B. J.: Source signatures of carbon monoxide and organic functional groups in asian pacific regional aerosol characterization experiment (ace-asia) submicron aerosol types, J. Geophys. Res.-Atmos., 108, 8637, doi:10.1029/2003jd003703, 2003. 
Matthew, B. M., Middlebrook, A. M., and Onasch, T. B.: Collection efficiencies in an aerodyne aerosol mass spectrometer as a function of particle phase for laboratory generated aerosols, Aerosol Sci. Technol., 42, 884-898, doi:10.1080/02786820802356797, 2008.

Minguillon, M. C., Perron, N., Querol, X., Szidat, S., Fahrni, S. M., Alastuey, A., Jimenez, J. L., Mohr, C., Ortega, A. M., Day, D., Lanz, V. A., Wacker, L., Reche, C., Cusack, M., Amato, F., Kiss, G., Hoffer, A., Decesari, S., Moretti, F., Hillamo, R., Teinila, K., Seco, R., Penuelas, J., Metzger, A., Schallhart, S., Muller, M., Hansel, A., Burkhart, J. F., Baltensperger, U., and Prevot, A. S. H.: Fossil versus contemporary sources of fine elemental and organic carbonaceous particulate matter during the daure campaign in northeast spain, Atmos. Chem. Phys., 11, 12607-12084, doi:10.5194/acp-11-12067-2011, 2011.

Mira-Salama, D., Gruning, C., Jensen, N. R., Cavalli, P., Putaud, J.-P., Larsen, B. R., Raes, F., and Coe, H.: Source attribution of urban smog episodes caused by coal combustion, J. Atmos. Res., 88, 294-304, 2008.

Mohr, C., DeCarlo, P. F., Heringa, M. F., Chirico, R., Slowik, J. G., Richter, R., Reche, C., Alastuey, A., Querol, X., Seco, R., Peñuelas, J., Jiménez, J. L., Crippa, M., Zimmermann, R., Baltensperger, U., and Prévôt, A. S. H.: Identification and quantification of organic aerosol from cooking and other sources in Barcelona using aerosol mass spectrometer data, Atmos. Chem. Phys., 12, 1649-1665, doi:10.5194/acp-12-1649-2012, 2012.

Ng, N. L., Canagaratna, M. R., Zhang, Q., Jimenez, J. L., Tian, J., Ulbrich, I. M., Kroll, J. H., Docherty, K. S., Chhabra, P. S., Bahreini, R., Murphy, S. M., Seinfeld, J. H., Hildebrandt, L., Donahue, N. M., DeCarlo, P. F., Lanz, V. A., Prevot, A. S. H., Dinar, E., Rudich, Y., and Worsnop, D. R.: Organic aerosol components observed in northern hemispheric datasets from aerosol mass spectrometry, Atmos. Chem. Phys., 10, 4625-4641, doi:10.5194/acp-10-4625-2010, 2010.

Ng, N. L., Canagaratna, M. R., Jimenez, J. L., Chhabra, P. S., Seinfeld, J. H., and Worsnop, D. R.: Changes in organic aerosol composition with aging inferred from aerosol mass spectra, Atmos. Chem. Phys., 11, 6465-6474, doi:10.5194/acp-11-64652011, 2011a.

Ng, N. L., Canagaratna, M. R., Jimenez, J. L., Zhang, Q., Ulbrich, I., and Worsnop, D.: Real-time methods for estimating organic component mass concentrations from aerosol mass spectrometer data, Environ. Sci. Technol., 45, 910-916, 2011 b.

Offenberg, J. H., Lewandowski, M., Jaoui, M., and Kleindienst, T. E.: Contributions of biogenic and anthropogenic hydrocarbons to secondary organic aerosol during 2006 in research Triangle Park, NC, Aerosol Air Qual. Res., 11, 99-U15, doi:10.4209/aaqr.2010.11.0102, 2011.

Paatero, P. and Tapper, U.: Positive matrix factorization a nonnegative factor model with optimal utilization of error-estimates of data values, Environmetrics, 5, 111-126, doi:10.1002/env.3170050203, 1994.

Pekney, N. J., Davidson, C. I., Zhou, L., and Hopke, P. K.: Application of PSCF and CPF to PMF-modeled sources of $\operatorname{PM}(2.5)$ in Pittsburgh, Aerosol Sci. Technol., 40, 952-961, doi:10.1080/02786820500543324, 2006.

Quinn, P. K., Bates, T. S., Coffman, D., Onasch, T. B., Worsnop, D., Baynard, T., de Gouw, J. A., Goldan, P. D., Kuster, W. C., Williams, E., Roberts, J. M., Lerner, B., Stohl, A., Petters- son, A., and Lovejoy, E. R.: Impacts of sources and aging on submicrometer aerosol properties in the marine boundary layer across the gulf of maine, J. Geophys. Res.-Atmos., 111, D23S36, doi:10.1029/2006JD007582, 2006.

Raatikainen, T., Vaattovaara, P., Tiitta, P., Miettinen, P., Rautiainen, J., Ehn, M., Kulmala, M., Laaksonen, A., and Worsnop, D. R.: Physicochemical properties and origin of organic groups detected in boreal forest using an aerosol mass spectrometer, Atmos. Chem. Phys., 10, 2063-2077, 2010,

http://www.atmos-chem-phys.net/10/2063/2010/.

Reid, J. S., Koppmann, R., Eck, T. F., and Eleuterio, D. P.: A review of biomass burning emissions part ii: Intensive physical properties of biomass burning particles, Atmos. Chem. Phys., 5, 799825, doi:10.5194/acp-5-799-2005, 2005.

Russell, L. M., Bahadur, R., Hawkins, L. N., Allan, J., Baumgardner, D., Quinn, P. K., and Bates, T. S.: Organic aerosol characterization by complementary measurements of chemical bonds and molecular fragments, Atmos. Environ., 43, 61006105, doi:10.1016/j.atmosenv.2009.09.036, 2009a.

Russell, L. M., Takahama, S., Liu, S., Hawkins, L. N., Covert, D. S., Quinn, P. K., and Bates, T. S.: Oxygenated fraction and mass of organic aerosol from direct emission and atmospheric processing measured on the $\mathrm{r} / \mathrm{v}$ ronald brown during texaqs/gomaccs 2006 , Journal of Geophysical, Research-Atmospheres, 114, D00F05, doi:10.1029/2008jd011275, 2009b.

Russell, L. M., Bahadur, R., and Ziemann, P. J.: Identifying organic aerosol sources by comparing functional group composition in chamber and atmospheric particles, Proc. Natl. Acad. Sci. USA, 108, 3516-3521, doi:10.1073/pnas.1006461108, 2011.

Schneider, J., Weimer, S., Drewnick, F., Borrmann, S., Helas, G., Gwaze, P., Schmid, O., Andreae, M. O., and Kirchner, U.: Mass spectrometric analysis and aerodynamic properties of various types of combustion-related aerosol particles, Int. J. Mass Spectrom., 258, 37-49, doi:10.1016/j.ijms.2006.07.008, 2006.

Schwartz, R. E., Russell, L. M., Sjostedt, S. J., Vlasenko, A., Slowik, J. G., Abbatt, J. P. D., Macdonald, A. M., Li, S. M., Liggio, J., Toom-Sauntry, D., and Leaitch, W. R.: Biogenic oxidized organic functional groups in aerosol particles from a mountain forest site and their similarities to laboratory chamber products, Atmos. Chem. Phys., 10, 5075-5088, doi:10.5194/acp-10-50752010, 2010.

Seinfeld, J. H. and Pandis, S. N.: Biogenic hydrocarbons, in: Atmospheric chemistry and physics 2 nd ed., John Wiley \& Sons, Inc., Hoboken, New Jersey, 43-46, 2006.

Setyan, A., Zhang, Q., Merkel, M., Knighton, W. B., Sun, Y., Song, C., Shilling, J. E., Onasch, T. B., Herndon, S. C., Worsnop, D. R., Fast, J. D., Zaveri, R. A., Berg, L. K., Wiedensohler, A., Flowers, B. A., Dubey, M. K., and Subramanian, R.: Characterization of submicron particles influenced by mixed biogenic and anthropogenic emissions using high-resolution aerosol mass spectrometry: Results from cares, Atmos. Chem. Phys., 12, 8131-8156, doi:10.5194/acp-12-8131-2012, 2012.

Shaw, P. M., Russell, L. M., Jefferson, A., and Quinn, P. K.: Arctic organic aerosol measurements show particles from mixed combustion in spring haze and from frost flowers in winter, Geophys. Res. Lett., 37, L10803, doi:10.1029/2010g1042831, 2010.

Shilling, J. E., Chen, Q., King, S. M., Rosenoern, T., Kroll, J. H., Worsnop, D. R., DeCarlo, P. F., Aiken, A. C., Sueper, D., Jimenez, J. L., and Martin, S. T.: Loading-dependent elemental 
composition of alpha-pinene soa particles, Atmos. Chem. Phys., 9, 771-782, doi:10.5194/acp-9-771-2009, 2009.

Simpson, I. J., Akagi, S. K., Barletta, B., Blake, N. J., Choi, Y., Diskin, G. S., Fried, A., Fuelberg, H. E., Meinardi, S., Rowland, F. S., Vay, S. A., Weinheimer, A. J., Wennberg, P. O., Wiebring, P., Wisthaler, A., Yang, M., Yokelson, R. J., and Blake, D. R.: Boreal forest fire emissions in fresh Canadian smoke plumes: $\mathrm{C}_{1}-\mathrm{C}_{10}$ volatile organic compounds (VOCs), $\mathrm{CO}_{2}, \mathrm{CO}, \mathrm{NO}_{2}$, $\mathrm{NO}, \mathrm{HCN}$ and $\mathrm{CH}_{3} \mathrm{CN}$, Atmos. Chem. Phys., 11, 6445-6463, doi:10.5194/acp-11-6445-2011, 2011.

Slowik, J. G., Cross, E. S., Han, J. H., Davidovits, P., Onasch, T. B., Jayne, J. T., WilliamS, L. R., Canagaratna, M. R., Worsnop, D. R., Chakrabarty, R. K., Moosmuller, H., Arnott, W. P., Schwarz, J. P., Gao, R. S., Fahey, D. W., Kok, G. L., and Petzold, A.: An inter-comparison of instruments measuring black carbon content of soot particles, Aerosol Sci. Technol., 41, 295-314, 2007.

Slowik, J. G., Stroud, C., Bottenheim, J. W., Brickell, P. C., Chang, R. Y. W., Liggio, J., Makar, P. A., Martin, R. V., Moran, M. D., Shantz, N. C., Sjostedt, S. J., van Donkelaar, A., Vlasenko, A., Wiebe, H. A., Xia, A. G., Zhang, J., Leaitch, W. R., and Abbatt, J. P. D.: Characterization of a large biogenic secondary organic aerosol event from eastern canadian forests, Atmos. Chem. Phys., 10, 2825-2845, 2010,

http://www.atmos-chem-phys.net/10/2825/2010/.

Sun, Y. L., Zhang, Q., Schwab, J. J., Demerjian, K. L., Chen, W. N., Bae, M. S., Hung, H. M., Hogrefe, O., Frank, B., Rattigan, O. V., and Lin, Y. C.: Characterization of the sources and processes of organic and inorganic aerosols in new york city with a high-resolution time-of-flight aerosol mass apectrometer, Atmos. Chem. Phys., 11, 1581-1602, doi:10.5194/acp-11-15812011, 2011.

Szidat, S., Ruff, M., Perron, N., Wacker, L., Synal, H. A., Hallquist, M., Shannigrahi, A. S., Yttri, K. E., Dye, C., and Simpson, D.: Fossil and non-fossil sources of organic carbon (oc) and elemental carbon (ec) in goteborg, sweden, Atmos. Chem. Phys., 9, 1521-1535, doi:10.5194/acp-9-1805-2009, 2009.

Taipale, R., Ruuskanen, T. M., Rinne, J., Kajos, M. K., Hakola, H., Pohja, T., and Kulmala, M.: Technical Note: Quantitative long-term measurements of VOC concentrations by PTR-MS measurement, calibration, and volume mixing ratio calculation methods, Atmos. Chem. Phys., 8, 6681-6698, doi:10.5194/acp8-6681-2008, 2008.

Takahama, S., Schwartz, R. E., Russell, L. M., Macdonald, A. M., Sharma, S., and Leaitch, W. R.: Organic functional groups in aerosol particles from burning and non-burning forest emissions at a high-elevation mountain site, Atmos. Chem. Phys., 11, 6367-6386, doi:10.5194/acp-11-6367-2011, 2011.

Takahama, S., Johnson, A., and Russell, L. M.: Quantification of carboxylic and carbonyl functional groups in organic aerosol infrared absorbance spectra, Aerosol Sci. Technol., 47, 310-325, doi:10.1080/02786826.2012.752065, 2013.

Ulbrich, I. M., Canagaratna, M. R., Zhang, Q., Worsnop, D. R., and Jimenez, J. L.: Interpretation of organic components from positive matrix factorization of aerosol mass spectrometric data, Atmos. Chem. Phys., 9, 2891-2918, doi:10.5194/acp-9-2891-2009, 2009.

Usher, C. R., Michel, A. E., and Grassian, V. H.: Reactions on mineral dust, Chem. Rev., 103, 4883-4939, doi:10.1021/cr020657y, 2003.
Vogel, A. L., Äijälä, M., Brüggemann, M., Ehn, M., Junninen, H., Petäjä, T., Worsnop, D. R., Kulmala, M., Williams, J., and Hoffmann, T.: Online atmospheric pressure chemical ionization ion trap mass spectrometry (APCI-IT-MSn) for measuring organic acids in concentrated bulk aerosol - a laboratory and field study, Atmos. Meas. Tech., 6, 431-443, doi:10.5194/amt-6-431-2013, 2013.

Wang, L., Atkinson, R., and Arey, J.: Dicarbonyl products of the oh radical-initiated reactions of naphthalene and the $\mathrm{C}_{1}$ - and $\mathrm{C}_{2}$-alkylnaphthalenes, Environ. Sci. Technol., 41, 2803-2810, doi:10.1021/es0628102, 2007.

Ward, J. H.: Hierarchical grouping to optimize an objective function, J. Am. Stat. Assoc., 58, 236-244, doi:10.2307/2282967, 1963.

Webb, P. J., Hamilton, J. F., Lewis, A. C., and Wirtz, K.: Formation of oxygenated-polycyclic aromatic compounds in aerosol from the photo-oxidation of o-tolualdehyde, Polycyclic Aromatic Compounds, 26, 237-252, doi:10.1080/07352680600903932, 2006.

Williams, B. J., Goldstein, A. H., Millet, D. B., Holzinger, R., Kreisberg, N. M., Hering, S. V., White, A. B., Worsnop, D. R., Allan, J. D., and Jimenez, J. L.: Chemical speciation of organic aerosol during the international consortium for atmospheric research on transport and transformation 2004: Results from in situ measurements, J. Geophys. Res.-Atmos., 112, D10S26, doi:10.1029/2006JD007601, 2007.

Williams, J., Crowley, J., Fischer, H., Harder, H., Martinez, M., Petaja, T., Rinne, J., Back, J., Boy, M., Dal Maso, M., Hakala, J., Kajos, M., Keronen, P., Rantala, P., Aalto, J., Aaltonen, H., Paatero, J., Vesala, T., Hakola, H., Levula, J., Pohja, T., Herrmann, F., Auld, J., Mesarchaki, E., Song, W., Yassaa, N., Nolscher, A., Johnson, A. M., Custer, T., Sinha, V., Thieser, J., Pouvesle, N., Taraborrelli, D., Tang, M. J., Bozem, H., Hosaynali-Beygi, Z., Axinte, R., Oswald, R., Novelli, A., Kubistin, D., Hens, K., Javed, U., Trawny, K., Breitenberger, C., Hidalgo, P. J., Ebben, C. J., Geiger, F. M., Corrigan, A. L., Russell, L. M., Ouwersloot, H. G., de Arellano, J. V. G., Ganzeveld, L., Vogel, A., Beck, M., Bayerle, A., Kampf, C. J., Bertelmann, M., Kollner, F., Hoffmann, T., Valverde, J., Gonzalez, D., Riekkola, M. L., Kulmala, M., and Lelieveld, J.: The summertime boreal forest field measurement intensive (HUMPPA-COPEC-2010): An overview of meteorological and chemical influences, Atmos. Chem. Phys., 11, 10599-10618, doi:10.5194/acp-11-10599-2011, 2011.

Wisthaler, A., Jensen, N. R., Winterhalter, R., Lindinger, W., and Hjorth, J.: Measurements of acetone and other gas phase product yields from the oh-initiated oxidation of terpenes by protontransfer-reaction mass spectrometry (ptr-ms), Atmos. Environ., 35, 6181-6191, 2001.

Yassaa, N. and Williams, J.: Analysis of enantiomeric and nonenantiomeric monoterpenes in plant emissions using portable dynamic air sampling/solid-phase microextraction (pdas-spme) and chiral gas chromatography/mass spectrometry, Atmos. Environ., 39, 4875-4884, doi:10.1016/j.atmosenv.2005.04.034, 2005.

Yassaa, N. and Williams, J.: Enantiomeric monoterpene emissions from natural and damaged scots pine in a boreal coniferous forest measured using solid-phase microextraction and gas chromatography/mass spectrometry, J. Chromatogr. A, 1141, 138144, 2007. 
Yassaa, N., Song, W., Lelieveld, J., Vanhatalo, A., Back, J., and Williams, J.: Diel cycles of isoprenoids in the emissions of norway spruce, four scots pine chemotypes, and in boreal forest ambient air during humppa-copec-2010, Atmos. Chem. Phys., 12, 7215-7229, doi:10.5194/acp-12-7215-2012, 2012.

Yokelson, R. J., Griffith, D. W. T., and Ward, D. E.: Openpath fourier transform infrared studies of large-scale laboratory biomass fires, J. Geophys. Res.-Atmos., 101, 21067-21080, doi:10.1029/96jd01800, 1996.

Yokelson, R. J., Crounse, J. D., DeCarlo, P. F., Karl, T., Urbanski, S., Atlas, E., Campos, T., Shinozuka, Y., Kapustin, V., Clarke, A. D., Weinheimer, A., Knapp, D. J., Montzka, D. D., Holloway, J., Weibring, P., Flocke, F., Zheng, W., Toohey, D., Wennberg, P. O., Wiedinmyer, C., Mauldin, L., Fried, A., Richter, D., Walega, J., Jimenez, J. L., Adachi, K., Buseck, P. R., Hall, S. R., and Shetter, R.: Emissions from biomass burning in the Yucatan, Atmos. Chem. Phys., 9, 5785-5812, doi:10.5194/acp-9-5785-2009, 2009.

Yttri, K. E., Simpson, D., Nojgaard, J. K., Kristensen, K., Genberg, J., Stenstrom, K., Swietlicki, E., Hillamo, R., Aurela, M., Bauer, H., Offenberg, J. H., Jaoui, M., Dye, C., Eckhardt, S., Burkhart, J. F., Stohl, A., and Glasius, M.: Source apportionment of the summer time carbonaceous aerosol at nordic rural background sites, Atmos. Chem. Phys., 11, 13339-13357, doi:10.5194/acp11-13339-2011, 2011.
Zhang, Q., Canagaratna, M. R., Jayne, J. T., Worsnop, D. R., and Jimenez, J. L.: Time- and size-resolved chemical composition of submicron particles in Pittsburgh: Implications for aerosol sources and processes, J. Geophys. Res.-Atmos., 110, D07S09, doi:10.1029/2004JD004649, 2005.

Zhang, Q., Jimenez, J. L., Canagaratna, M. R., Allan, J. D., Coe, H., Ulbrich, I., Alfarra, M. R., Takami, A., Middlebrook, A. M., Sun, Y. L., Dzepina, K., Dunlea, E., Docherty, K., DeCarlo, P. F., Salcedo, D., Onasch, T., Jayne, J. T., Miyoshi, T., Shimono, A., Hatakeyama, S., Takegawa, N., Kondo, Y., Schneider, J., Drewnick, F., Borrmann, S., Weimer, S., Demerjian, K., Williams, P., Bower, K., Bahreini, R., Cottrell, L., Griffin, R. J., Rautiainen, J., Sun, J. Y., Zhang, Y. M., and Worsnop, D. R.: Ubiquity and dominance of oxygenated species in organic aerosols in anthropogenically-influenced northern hemisphere midlatitudes, Geophys. Res. Lett., 34, L13801, doi:10.1029/2007GL029979, 2007.

Zhang, Q., Jimenez, J. L., Canagaratna, M. R., Ulbrich, I. M., Ng, N. L., Worsnop, D. R., and Sun, Y.: Understanding atmospheric organic aerosols via factor analysis of aerosol mass spectrometry: A review, Anal. Bioanal. Chem., 401, 3045-3065, doi:10.1007/s00216-011-5355-y, 2011. 